\title{
Competitividade de destinos turísticos: o caso das ilhas de Cabo Verde
}

\author{
Milene Monteiro* Paula Odete Fernandes** \\ Instituto Politécnico de Bragança (Portugal)
}

\begin{abstract}
Resumo: O principal objetivo deste trabalho de investigação focaliza-se no estudo da avaliação do desempenho e da competitividade dos destinos turísticos das ilhas de Cabo Verde por principais mercados emissores, tendo por base os dados das dormidas mensais nos estabelecimentos hoteleiros para o período de 2005 a 2011. Utilizou-se para o efeito o instrumento da Análise da Quota de Mercado proposto por Faulkner (1997), bem como o índice de Gini e a Dissemelhança entre os destinos turísticos nos principais mercados emissores, para melhor complementar o estudo em análise. Os resultados obtidos revelaram que as ilhas registaram alterações na competitividade turística, apresentaram níveis de competitividade turística distintos para as várias origens. Em relação ao Índice de Gini, em termos nacionais verificou-se uma diminuição de concentração de dormidas. Quanto à dissemelhança, a ilha da Boavista foi a região mais singular e os pares São Nicolau e Brava foram as mais semelhantes entre si.
\end{abstract}

Palavras-chave: Competitividade Turística, Análise da Quota de Mercado, Índice de Gini, Arquipélago de Cabo Verde, Destinos Turísticos.

\section{Tourism destinations competitiveness: the case of Cape Verde islands}

Abstract: The main goal of this research focuses on studying the performance and competitiveness of tourism destinations of the Cape Verde islands by main outbond markets. It was used the data of monthly overnight stays in hotels for the period 2005 to 2011. For that it was used the instrument Analysis of Market Share proposed by Faulkner (1997), as well as the Gini Index and the Dissimilarity among tourist destinations in major outbound markets, to better complement the study analysis. The results showed that the islands have changed in the tourism competitiveness, presented levels of tourism competitiveness different for the various origins. Concerning the Gini Index, nationally there was a decrease in concentration of overnights. As the dissimilarity, the island of Boavista was the most singular region and São Nicolau and Brava were the most similar.

Keywords: Tourism Competitiveness, Analysis of Market Share, Gini Index, Cape Verde Islands, Tourism Destinations.

\section{Introdução}

O setor do turismo constitui uma oportunidade de desenvolvimento económico e social, que resulta não só da importância e das perspetivas de crescimento futuro que o setor tem e terá na economia mundial, mas também das transformações que tanto a oferta como a procura irão conhecer, transformações que resultarão ainda na dinamização de novos produtos turísticos e da exploração de novos segmentos de mercado. Este setor tem crescido de forma global nos últimos tempos, contribuindo para geração de empregos, receitas e impostos, além de aumentar o Produto Interno Bruto (PIB).

Os sucessivos Governos do arquipélago de Cabo Verde têm apostado no setor do Turismo como principal veículo do desenvolvimento económico e social do país. As tendências de evolução do Turismo apontam

** Mestre em Gestão das Organizações (IPB/APNOR). Instituto Politécnico de Bragança; E-mail:mims_monteiro90@hotmail.com.
Professora Coordenadora do Instituto Politécnico de Bragança. Doutorada em Economia e Gestão pela Universidade de Valladolid.
Coordenadora Científica e Investigadora da Unidade de Investigação Aplicada em Gestão (UNIAG/APNOR); E-mail:pof@ipb.pt 
para a globalização dos destinos, uma diversificação cada vez maior da procura e uma diferenciação do produto. A riqueza cultural, o contraste natural, a especificidade de cada ilha permite pensar em projetar o arquipélago a nível mundial como um destino privilegiado.

O principal objetivo deste trabalho será o desempenho e avaliação da competitividade dos destinos turísticos das ilhas de Cabo Verde. Para tal, utilizou-se como objeto de estudo "Dormidas mensais, nos estabelecimentos hoteleiros, nas ilhas de Cabo Verde" registadas no período de Janeiro de 2005 a Dezembro de 2011.

No sentido de dar resposta ao objetivo do presente trabalho de investigação utilizou-se como suporte metodológica literatura publicada na área do turismo e economia aplicada. Ainda, e como suporte empírica teve-se por base, artigos científicos. Vários são os estudos científicos publicados tendo por base a competitividade dos destinos turísticos (Ritchie \& Crouch, 2000; Dwyer \& Kim, 2003). Para determinar a competitividade das ilhas de Cabo Verde utilizou-se o modelo de competitividade proposto por Faulkner (1997), e ainda o Índice de Gini e medidas de concentração para complementar o estudo. A escolha da Análise de Competitividade de Faulkner (1997) deveu-se ao fato de considerá-lo o mais adequado para o problema em estudo e por ser um dos mais utlizados nos estudos de competitividade de destinos turísticos

O presente estudo encontra-se estruturado em três pontos, além do presente ponto e da conclusão. No segundo ponto vai abordar-se a temática competitividade dos destinos turísticos, bem como a caraterização do arquipélago de Cabo Verde. No terceiro ponto indica-se a metodologia de investigação, com o objetivo de estudo, os instrumentos de recolhas de dados e tratamento dos dados. No quarto ponto apresentam-se a caraterização da oferta e da procura turística das ilhas, bem como o resultado da Análise da Quota de Mercado para os destinos e as principais origens. Por último, apresentam-se as principais conclusões, e ainda sugerem-se algumas linhas de investigação futuras.

\section{Enquadramento teórico}

\subsection{A Competitividade dos Destinos Turísticos}

Destino significa o lugar definido para o fim de uma viagem, ou seja, uma área geográfica (um local, um resort, uma região, um país, etc.) onde o viajante tem a intenção de passar um tempo longe de casa (Manente, 2008). Segundo o mesmo autor um destino turístico é um lugar visitado por turistas que representa a unidade básica de análise em turismo. Três perspetivas podem ser reconhecidas:

- A geográfica (uma área claramente reconhecível com fronteiras geográficas ou administrativas que os turistas visitam e ficar em durante a viagem);

- O económico (o lugar onde eles ficam mais tempo e gastam uma quantia relevante de dinheiro e onde as receitas do turismo é significativo, ou potencialmente significativo, para a economia);

- O psicográfico (o que constitui a principal razão para a viagem).

O destino turístico pode ser associado a um determinado espaço geográfico - cidade, região ou país, com características climáticas, culturais, históricas e sociais que aglutinam e orientam as unidades de gestão que o constituem e se traduzem numa plataforma de serviços integrada, ou seja, os recursos, as atrações e as empresas dos diversos sectores, prestam serviços de forma complementar e dirigidos à satisfação dos turistas que de acordo com as suas preferências, experimentam o que o destino tem para oferecer; possui capacidade para identificar e selecionar as atrações e características pelas quais se quer promover e que o tornam objetivo de visita e elemento central da experiência turística; tem capacidade de desenvolver instrumentos de planificação, administração e comercialização (Barbeitos, 2011).

Pode ser ainda entendido como um aglomerado de lugares que produz experiências para as diferentes tipologias de turistas (Marujo \& Cravidão, 2012).

Buhalis (2000) refere que os destinos turísticos constituem uma experiência integrada para o consumidor e que são amálgamas de produtos e de ofertas. Para este autor, os destinos são compostos pelo que ele denomina de seis A's:

- Atrações (Atractions): Naturais, construídas pelo Homem, artificiais, construídas para um propósito específico, culturais, para eventos especiais;

- Acessibilidades (Acessibility): Sistema de transportes globais, incluindo estradas, terminais e veículos; 
- Comodidades (Amenities): Estabelecimentos de alojamento e restauração, comércio e outros serviços turísticos;

- Pacotes disponíveis (Available packages): Pacotes turísticos pré-concebidos por intermediários;

- Atividades (Activities): Todas as atividades disponíveis no sistema e das quais os turistas irão usufruir durante a sua estádia;

- Serviços Auxiliares (Ancillary Services): Serviços utilizados pelos turistas, como bancos, telecomunicações, correios, hospitais, etc.

Ainda Buhalis (2000) refere que se pode examinar o conceito de destino turístico segundo duas perspetivas. Por um lado, os destinos turísticos podem ser áreas geograficamente definidas, entendidas pelos seus visitantes como uma entidade única, com um quadro legal e político de gestão do marketing e do planeamento turístico. Por outro lado, os destinos turísticos podem constituir conceitos perpetuais, que são interpretados de forma subjetiva pelos turistas em função do seu itinerário de viagem, da experiência cultural, dos motivos da visita, nível educacional e experiências pessoais.

A competitividade dos destinos turísticos é determinada pela capacidade de criar, produzir, distribuir e lou fornecer produtos em mercados para a obtenção de retornos crescentes internacionais sobre os seus recursos, sendo considerado um conceito dinâmico (Scott \& Lodge, 1985).

Para Benz e Furst (2002), a competitividade das regiões pode ser determinada pela sua habilidade de organizar "processos de aprendizagem endógenos", bem como criar as estruturas favoráveis à transferência para a aprendizagem da política.

Competitividade de um destino turístico parece estar relacionada com a capacidade de um destino fornecer bens e serviços melhor do que outros destinos (Dwyer \& Kim, 2003). Estes autores afirmam que a competitividade de um destino turístico é um conceito geral que engloba os diferenciais de preços, juntamente com movimentos de taxa de câmbio, os níveis de produtividade de vários componentes da indústria turística e fatores qualitativos afetando ou não a atratividade de um destino turístico.

O modelo de Dwyer e Kim (2003) também considera a teoria da competitividade nacional, bem como os principais elementos da competitividade de destino turístico, tal como proposto pelos investigadores do turismo e muitas das variáveis identificadas por Ritchie e Crouch (1999, 2000). O modelo pretende possibilitar comparações entre países e entre setores do turismo, oferecendo fusão dos principais elementos destacados na literatura geral sobre competitividade com as características peculiares dos destinos turísticos. Esse modelo reconhece a competitividade como objetivo intermediário para o alcance do fim maior, que consiste na prosperidade regional e nacional. Associado ao modelo, há um conjunto de indicadores que os autores supõem ser adequado para medir a competitividade de qualquer destino turístico. O modelo apresenta diferentes elementos interligados e responsáveis por alguma dimensão da competitividade do destino (Costa \& Hoffmann, 2006).

Os indicadores de competitividade do destino incluem tanto atributos subjetivos (o 'encanto' do destino ou a 'beleza cénica') como atributos determinados objetivamente (quota de mercado turístico, receitas do turismo, etc.), enquanto os indicadores de prosperidade socioeconómica fazem referência a variáveis macroeconómicas como os níveis de produtividade da economia, níveis de emprego, taxa de crescimento económico, etc.

\subsection{Cabo Verde e as suas ilhas}

O arquipélago de Cabo Verde é constituído por dez ilhas, nove habitadas e uma desabitada (Figura 1). A região é dominada pelos ventos Alísios, que sopram de nordeste quase todo o ano, e estão na origem do vento típico constante das ilhas, da navegação bastante tranquila, e da temperatura quase sempre amena (Cabo Verde, 2013). Sobretudo entre Dezembro e Março ocorre frequentemente no arquipélago um fenómeno particular, uma bruma seca levantada e transportada pelos ventos alísios, provocando falta de visibilidade. A estação das chuvas decorre entre os meses de Julho e Outubro, com precipitação mensal e sazonal bastante irregular. As ilhas dividem-se em "Barlavento" (as ilhas onde sopra o vento) e "Sotavento" (as ilhas do lado oposto onde sopra o vento). As ilhas do Barlavento são: Sal, Santo Antão, São Vicente, São Nicolau e Boavista (ilhas habitadas) e Santa Luzia (desabitada). As ilhas de Sotavento são: Maio, Santiago, Brava e Fogo (habitadas). 
Figura 1: Arquipélago de Cabo Verde.

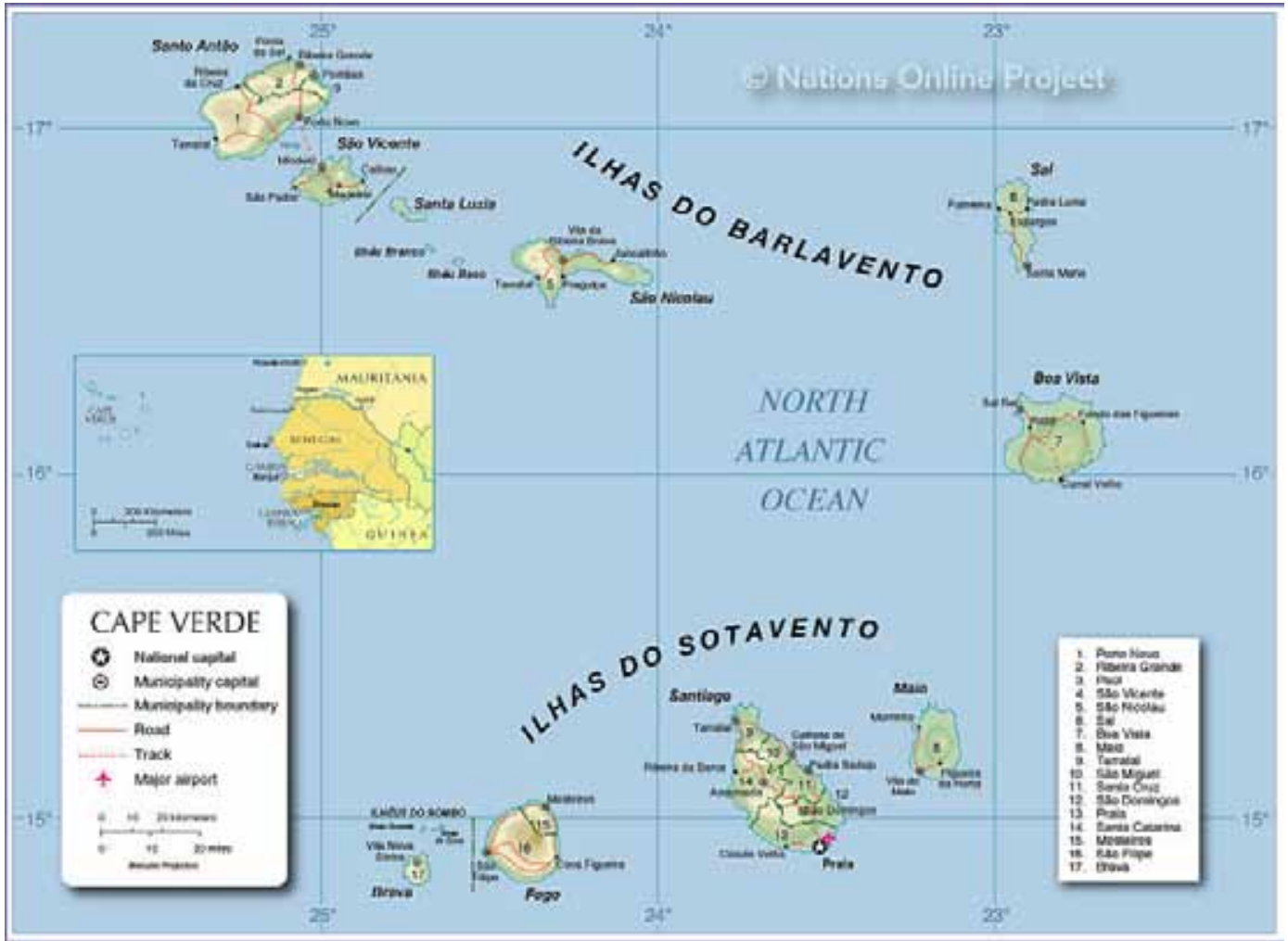

Fonte: www.nationsonline.org (2014).

O país tem um clima do tipo quente, subtropical seco, com uma temperatura média anual de $25^{\circ}$, características que conferem às ilhas - juntamente com a sua localização e a origem vulcânica. Estas condições naturais específicas, a par de uma cultura marcante e diversificada e de uma história rica, constituem um dos mais importantes atrativos do país no que diz respeito à sua competitividade como destino turístico, não obstante a sua fragilidade em termos de equilíbrio ambiental, que requer uma abordagem cuidadosa no quadro do desenvolvimento da atividade turística.

O turismo é o principal setor da economia de Cabo Verde, segundo o World Travel and Tourism Council (WTTC) terá tido um contributo direto de 15.3\% para o PIB em 2012 (contributo total 44.1\%) (WTTC, 2014). Este setor tem sabido captar novos segmentos de procura ligados ao turismo de cruzeiro e á náutica de recreio. De acordo com a OMT (2013), Cabo Verde é o 10. ${ }^{\circ}$ país à escala global em termos da importância relativa do setor do turismo para a sua economia, sendo o $12 .^{\circ}$ no que concerne às expetativas de crescimento para o setor. Este cenário traduz-se na evolução crescente da capacidade de alojamento no arquipélago e maior qualidade das infraestruturas e recursos humanos disponibilizados.

\section{Metodologia de investigação}

\subsection{Objetivo do estudo}

Existem diferentes métodos que permitem analisar a competitividade dos destinos turísticos, porém no presente trabalho vai utilizar-se a Análise da Quota de Mercado, instrumento desenvolvimento por Bill Faulkner em 1997. Ainda, serão utilizados o Índice de Gini e a Dissemelhança entre os destinos turísticos nos principais mercados emissores. 
Neste contexto, o principal objetivo do presente trabalho centra-se em analisar o posicionamento competitivo, por mercado emissor, dos destinos turísticos do arquipélago de Cabo Verde, ou seja, estudar a competitividade turística por ilha (as nove ilhas - destinos turísticos - que formam o arquipélago).

Para concretização do principal objetivo, pretende-se ainda contribuir com um melhor conhecimento do setor turístico, por ilha em estudo, sob o ponto de vista da quota e da procura onde vão ser analisados os seguintes indicadores: dormidas registadas nos estabelecimentos hoteleiros, hóspedes registados, permanência dos hóspedes, taxa de ocupação e índice de preferência. Ainda, analisar a evolução de cada uma das ilhas em relação aos principais mercados emissores (Suíça, Portugal, Itália, Reino Unido, França, Estados Unidos da América, Espanha, Bélgica e Holanda, Áustria, Alemanha e África do Sul), bem como analisar a evolução para o TOP 4 (quatro principais mercados emissores do arquipélago de Cabo Verde) em relação aos nove destinos turísticos.

De referir que o horizonte temporal considerado assentou entre os anos de 2005 a 2011 (último ano com dados publicados oficialmente pelo Instituto Nacional de Estatística de Cabo Verde).

\subsection{Tratamento dos Dados}

Para avaliar o desempenho e a competitividade dos destinos turísticos em estudo, sob o ponto de vista da procura turística, tal como se referiu vai recorrer-se à Análise de Quotas de Mercado [AQM]. Assim, tendo como base a avaliação dos mercados emissores, a AQM analisa-se sob duas dimensões, a saber (Águas, Grade \& Sousa, 2003; Fernandes, 2005; Fernandes, Teixeira, Ferreira \& Azevedo, 2008):

um índice de desvio da quota de mercado, designado por [B], dado pela seguinte equação:

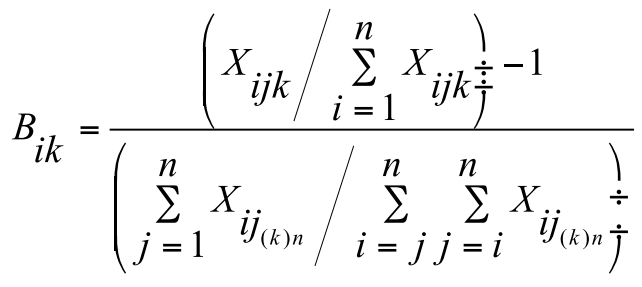

onde,

$B_{i k}$, índice de desvio da quota de mercado para o destino $i$ no ano $k$;

$X_{i j k}$, número de visitantes para o destino $i$ do mercado emissor $j$, no ano k;

$n$, número de mercados, tanto de emissores como de destinos.

um índice de variação da quota de mercado [C], obtido pela seguinte expressão:

$$
C_{0-k}=\left[\left(X_{i j k} / X_{i j 1}\right)-1\right]-\left[\left(X_{j k} / X_{j j} \dot{j}^{-}-1\right.\right.
$$

onde,

$\mathrm{C}_{0-}$

$0-k$, índice de variação da quota de mercado entre o momento 0 e o momento $\mathrm{k}$;

$X_{j k}$, total do número de visitantes do mercado emissor $j$ no ano $k$;

$X_{i j k}$, número de visitantes para o destino $i$ do mercado emissor $j$, no ano k;

$1 . . k$, do ano 1 ao ano $k$. 
Relativamente à primeira dimensão [B], é um indicador estático, que na ótica de análise do destino, reflete a comparação da quota de mercado do destino $i$ do mercado emissor $j$ com a quota de mercado média do destino $i$ no conjunto de mercados emissores em estudo num determinado momento (Águas, Grade \& Sousa, 2003; Fernandes, 2005; Fernandes, Teixeira, Ferreira \& Azevedo, 2008).

Por outro lado, no que diz respeito à segunda dimensão [C], é um indicador dinâmico que na ótica de análise do destino relaciona, num determinado intervalo de referência, a taxa de crescimento dos fluxos turísticos a partir do mercado emissor $j$ para o destino $i$ com a taxa de crescimento dos fluxos turísticos a partir do mercado emissor $j$ para o conjunto dos destinos concorrentes em estudo, num determinado período de análise (Águas, Grade \& Sousa, 2003; Fernandes, 2005; Fernandes, Teixeira, Ferreira \& Azevedo, 2008).

Desta forma, de acordo com os valores obtidos para cada um dos índices, os mesmos podem ser representados graficamente num sistema de eixos ortogonal, onde [C] representa-se no eixo horizontal e [B] no eixo vertical, permitindo a determinação de quatro quadrantes (Figura 2).

Figura 2: Análise da Quota de Mercado

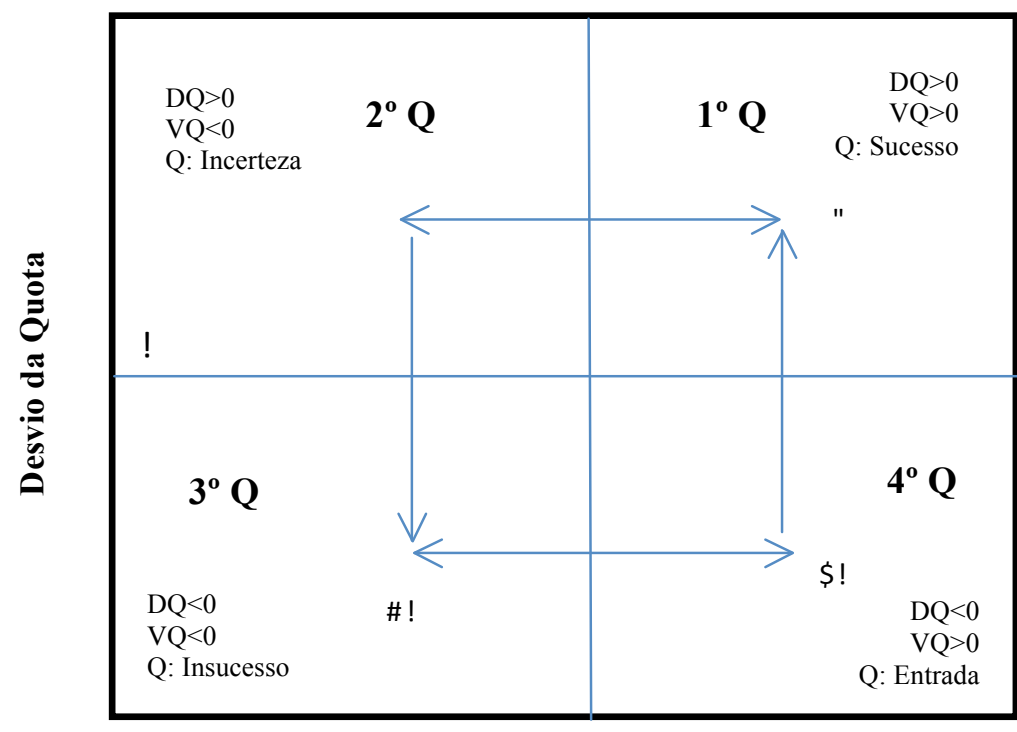

Variação da Quota

Adaptado de Faulkner, 1997, p.29

Pode ainda ser estabelecida uma correspondência com o modelo do ciclo de vida do produto, apresentando as seguintes particularidades (Águas, Grade \& Sousa, 2003; Fernandes, 2005; Fernandes, Teixeira, Ferreira \& Azevedo, 2008):

1. ${ }^{\circ}$ Quadrante: $\mathrm{DQ}>0$ e VQ $>0$ - Origens em que o destino já possui uma quota de mercado acima da média e em que se encontra a ganhar quota de mercado (Q: Sucesso).

$2 .^{\circ}$ Quadrante: $\mathrm{DQ}>0$ e $\mathrm{VQ}<0$ - Origens em que o destino dispõe uma quota de mercado acima da média mas em que se encontra a perder quota de mercado (Q: Incerteza).

3. ${ }^{\circ}$ Quadrante: $\mathrm{DQ}<0$ e $\mathrm{VQ}<0$ - Origens em que o destino apresenta uma quota de mercado abaixo da média e em que se encontra a perder quota de mercado (Q: Insucesso).

4. ${ }^{\circ}$ Quadrante: $\mathrm{DQ}<0$ e VQ $>0$ - Origens em que o destino detém uma quota de mercado abaixo da média mas em que se encontra a ganhar quota de mercado (Q: Entrada).

De referir que a AQM para um conjunto de destinos turísticos apresenta algumas caraterísticas que merecem ser conhecidas (Águas, Grade \& Sousa, 2003): 
- Os valores das variações de quota são independentes, pelo que poderão ser todos do mesmo sinal ou de sinais opostos. Quanto maior o número de origens com variação de quota positiva mais favorável a posição global de crescimento do destino, a qual também é influenciada pela dimensão dos mercados emissores.

- Excluindo a situação limite em que um destino regista quotas de mercado idênticas em todas as origens e, por consequência, todos os DQi nulos, por definição, os desvios de quota nunca poderão ser todos do mesmo sinal.

- Não há uma relação determinística entre variação de quota e desvio de quota. Tendencialmente, variações de quota positivas conduzirão a aumentos do desvio de quota, e vice-versa, embora tal não ocorra em todos os casos. Basta ter presente que todas as variações de quota podem ser do mesmo sinal não podendo acontecer o mesmo com as variações de desvios de quota.

- A impossibilidade de presença de todas as origens no mesmo quadrante pressupõe que a fase do ciclo de vida do destino não pode ser idêntico, em simultâneo, em todas as origens, o que se revela plausível.

Quando se pretende realizar uma Análise da Quota de mercado torna-se necessário decidir sobre as seguintes situações (Águas, Grade \& Sousa, 2003; Fernandes, 2005):

- Qual a variável do desempenho (ex.: dormidas, hóspedes, turistas, receitas);

- Qual o conjunto de origens que se pretende analisar;

- Qual o conjunto de destinos que se pretende avaliar;

- Escolher o horizonte temporal (dois momentos distintos).

Uma vez obtidos todos os valores de Variação da Quota e de Desvio da Quota para todos os destinos, pode-se também realizar uma análise por origem, a qual é mais indicada e estudar a posição de um determinado destino em relação aos seus concorrentes.

Para avaliar o grau de concentração das dormidas das principais origens vai recorrer-se ao Índice de Gini. Hoffmann (1998) afirma que o Índice de Gini é uma medida de desigualdade desenvolvida pelo estatístico italiano Corrado Gini e publicada no documento "Variabilità e Mutabilità" em 1912. Este índice é utilizado para calcular a desigualdade de distribuição de renda, mas pode ser usada também para qualquer distribuição, como a concentração de dormidas. O Índice de Gini varia entre 0 e 1 , sendo que quanto mais próximo do zero menor é a desigualdade de renda num país, ou seja, melhor a distribuição de renda. Quanto mais próximo do um, maior a concentração de rendimento num país. O mesmo autor refere que no caso das concentrações das dormidas, o valor 0 verifica-se quando o número de dormidas é igual para todas as origens e o valor 1 quando só se registam dormidas a partir de uma das origens. Ou seja, quanto maior o valor do Índice de Gini maior a concentração das dormidas.

O grau de concentração das dormidas avaliado pelo índice de Gini, pode ser dada pela seguinte equação (Águas, Grade \& Sousa, 2003):

$I G=\frac{\sum_{i=1}^{n-1}(p i-q i)}{1 !}=1-\frac{\sum_{i=1}^{n} q i}{\sum_{i=1}^{n-1} p i}, \quad$ com $p i=\frac{c u m F i}{\sum F i}$ eqi $=\frac{c u m Y i}{\sum V i}$

onde,

cum $\mathrm{Fi}$ = frequências acumuladas para cada origem ou destino, por crescente em relação ao atributo (dormidas);

cum $Y i=$ frequências acumuladas das dormidas da origem ou no destino ;

$p i=$ cum $F i$ em relação ao total de origens ou destinos;

$q i=$ cum Yi em relação ao total de dormidas da origem ou no destino;

$n=$ número origens ou destinos em análise.

Ainda, através da análise da dissemelhança entre os destinos turísticos nas principais origens, procura-se avaliar a existência ou não da conflitualidade regional. Para tal, e para cada par de destinos turísticos, entrou-se em linha de conta com a contagem do número de vezes que os pares de destinos turísticos não se repetem no mesmo quadrante. Esta técnica foi apresentada por Águas, Grade e Susa (2003). 


\section{Competitividade dos destinos turísticos: o caso das ilhas de cabo verde}

\subsection{Caraterização da Oferta}

De acordo com os relatórios realizados pelo Instituto Nacional de Estatística de Cabo Verde, de 2005 a 2011 o número de estabelecimentos hoteleiros passou de 132 para 195 no arquipélago de Cabo Verde. Esses estabelecimentos hoteleiros ofereciam, em 2011, uma capacidade de alojamento de 7.901 quartos, 14.076 camas, 17.025 lugares e 5.178 pessoal ao serviço.

Figura 3: Taxa de Variação Média anual dos estabelecimentos hoteleiros, por destinos turísticos, $(2005-2011)$

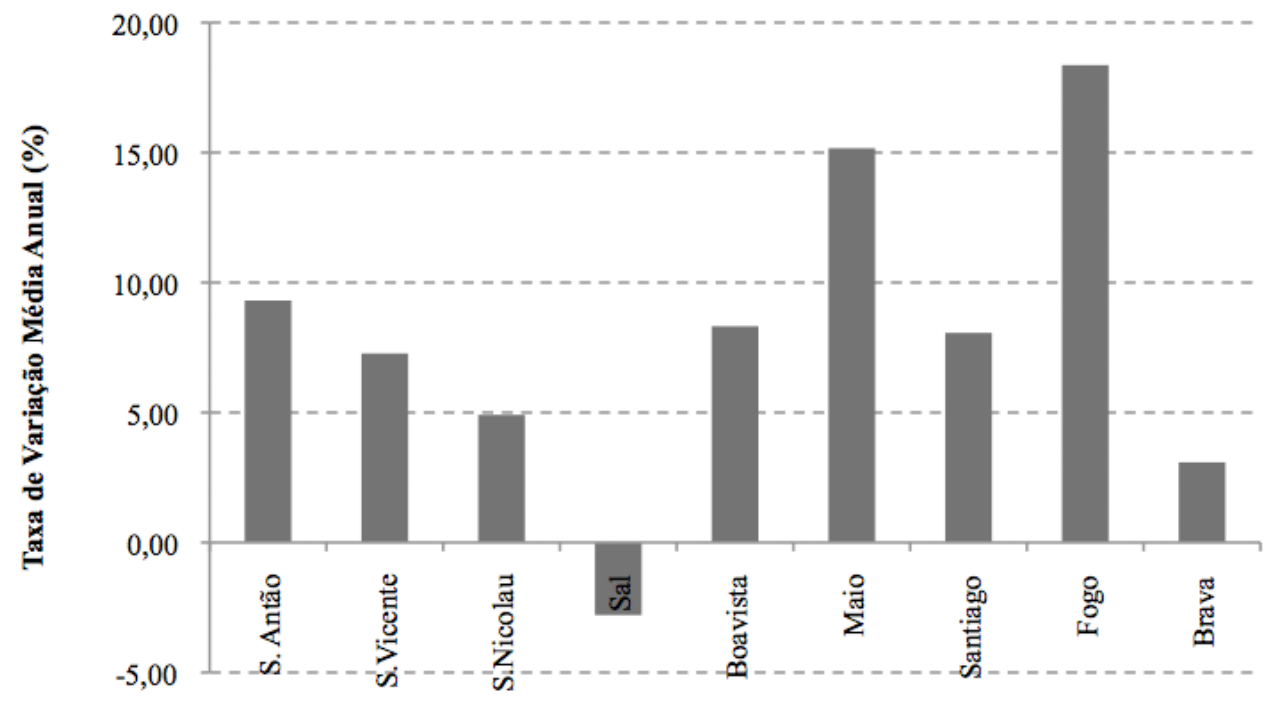

Ilhas de Cabo Verde

Pela análise aos valores apresentados na Figura 3, pode dizer-se que:

- de 2005 a 2011, a ilha do Fogo teve maior crescimento absoluto em termos de número de estabelecimentos, ou seja, mais 14 estabelecimentos correspondente a uma taxa de variação média anual de 18,36\%. Seguem as ilhas do Maio e Santo Antão com uma variação média anual de 15,17\% e $9,31 \%$ respetivamente;

- a ilha de Boavista aumentou mais 8 estabelecimentos, dos 13 que possuía em 2005 passou para 21 em 2011, o que representa uma taxa de variação média anual de 8,32\%;

- as ilhas de Santiago, São Vicente, São Nicolau e Brava tiveram crescimentos menos significativos, com uma taxa de variação média anual de 8,06\%, 4,91\%, 3,09\%, respetivamente;

- na ilha do Sal verificou-se um decréscimo de 5 estabelecimentos o que corresponde a uma taxa de variação média anual de $-2,79 \%$.

- Ao longo do período 2005-2011, por tipo de estabelecimentos hoteleiros, verificou-se aumento significativo nas pensões, mais de 32 estabelecimentos correspondente a uma taxa de variação média anual de $78,2 \%$. Seguem-se os hotéis com um incremento de 11 estabelecimentos com uma taxa de variação média anual de 49,1\%. Nas residências, nos aldeamentos turísticos e os hotéis-apartamento aumentaram de 8, 7 e 5 estabelecimentos, respetivamente. Nas pousadas, não se registou aumento de estabelecimentos. 


\subsection{Caraterização da Procura}

O número de dormidas consiste na permanência de um indivíduo num estabelecimento que fornece alojamento por um período compreendido entre as 12 horas de um dia e as 12 horas do dia seguinte (INE, 2012). Analisando a Figura 4 verifica-se que o comportamento do número de dormidas em Cabo Verde tem uma tendência positiva, ou seja, pode dizer-se que que as dormidas triplicaram. Este aumento pode dever-se a diversos fatores turísticos desde aumento da oferta turística, aumento de campanhas promocionais entre outros.

Figura 4: Evolução do número de dormidas, para o período 2005-2011

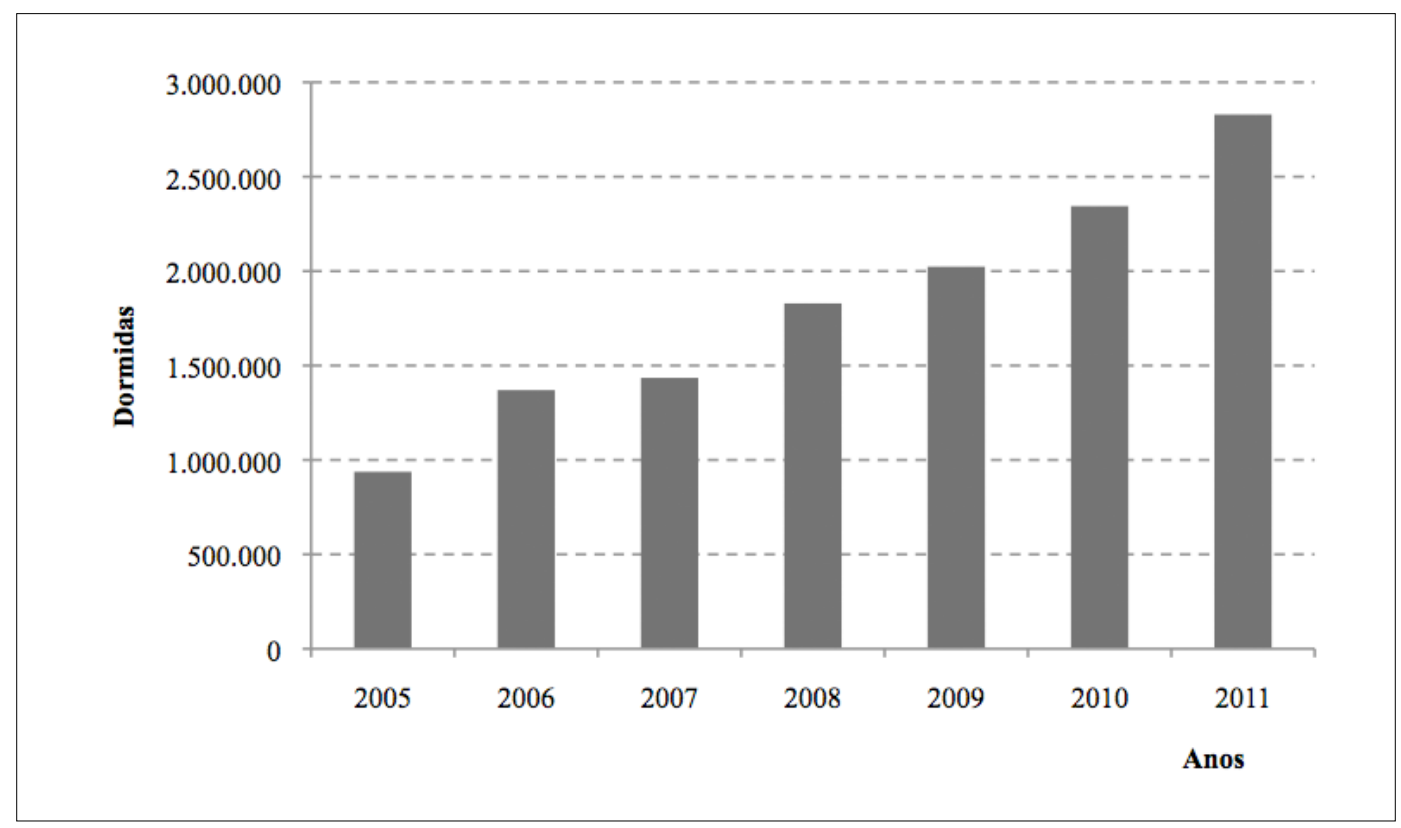

O número de dormidas em Cabo Verde teve uma evolução positiva de 2005 para 2011, sendo que em 2006, foi o ano em que o número de dormidas registou uma variação anual positiva mais elevada, de $46 \%$, seguindo-se o ano de 2011 que foi de $21 \%$.

Atendendo aos principais mercados emissores, pode dizer-se que:

- Em 2005, o principal mercado emissor foi a Itália seguido de Portugal;

- No ano de 2011 registou-se o Reino Unido como principal mercado emissor.

Com a distribuição do número de dormidas no período de análise verifica-se um peso determinante do destino as ilhas do Sal e Boavista. Ainda:

- Em 2006, o número de dormidas aumentou significativamente nas ilhas de São Vicente, Sal, Boavista e Santiago. Nas restantes ilhas o número de dormidas aumentou normalmente com exceção das ilhas de Santo Antão, Maio e Brava onde se verificou um decréscimo no número de dormidas em relação ao ano anterior;

- Em 2007, verifica-se um aumento na ilha do Sal, Fogo e Brava, nas restantes verificou-se um pequeno decréscimo no número de dormidas;

- Em 2008, a ilha do Sal continua a ser um dos destinos de preferência a semelhança dos anos anteriores, registando um pequeno aumento nas ilhas de Santo Antão e Santiago. Nesse mesmo período, registou-se um aumento significativo na ilha da Boavista e um pequeno decréscimo nas restantes ilhas;

- Em 2009, registou-se um pequeno decréscimo na ilha do Sal não deixando de ser mesmo assim o destino de preferência. Na ilha de Santo Antão, Boavista e Maio registou-se um aumento significativo e nas restantes um ligeiro decréscimo; 
- Em 2010, houve um aumento ligeiro nas ilhas de São Vicente, Sal, Maio, Fogo e um aumento significativo nas ilhas de Boavista e Brava. Nas restantes ilhas verificou-se um ligeiro decréscimo;

- Em 2011, registou-se um aumento significativo na ilha de Santo Antão e São Nicolau e um aumento ligeiro nas ilhas de São Vicente, Sal, Boavista e Santiago. Nas restantes ilhas registou-se um pequeno decréscimo. Neste mesmo período a ilha de Boavista passou a ser o destino de preferência.

O número de hóspedes apresenta um aumento significativo ao longo dos últimos 6 anos, em Cabo Verde. Este aumento pode dever-se aos fatores existentes referidos na análise anterior, aquando da análise das dormidas. De referir que em 2011 cerca de 2.827 .562 dormidas foram realizadas por 475.294 hóspedes. De 2005 a 2010 registou-se o maior número de hóspedes na ilha do Sal, sendo que em 2009 a ilha da Boavista passou a registar um número elevado de hóspedes registados. A ilha de Santiago manteve-se ao longo dos anos em estudo terceira ilha com o maior número de hóspedes.

A taxa de ocupação cama líquida aumentou ao longo dos 6 anos em análise. Em 2005 a taxa de ocupação registou-se uma variação média anual de 40\% e em 2011 aumentou para 58\%. No sentido de fazer uma análise comparativa por ilha, da taxa de ocupação-cama líquida pode dizer-se que as ilhas com maior taxa de ocupação, ao longo dos anos em estudo, foram a ilha do Sal, Boavista e a ilha de Santiago. A ilha do Sal foi a ilha que registou uma maior taxa de ocupação no ano de 2005 a 2008. Em 2009 a ilha de Boavista passou a ser a ilha com maior taxa de ocupação.

A permanência média dos hóspedes em Cabo Verde aumentou ao longo dos anos em estudo. Entre 2005 e 2011 pode verificar-se que os hóspedes permanecem entre 2 e 9 noites, no destino turístico Cabo Verde. Constatou-se que:

- em 2005, os hóspedes permaneciam mais dias nas ilhas de Santo Antão, Sal e Boavista, ou seja, os turista permaneciam cerca de 7 dias na ilha de Santo Antão, 4 dias na ilha do Sal e 5 dias na ilha da Boavista;

- em 2006, os hóspedes permaneciam mais dias na ilha da Boavista, cerca de 8 dias, seguindo-se a ilha do Sal onde permaneciam 6 dias;

- em 2007, as ilhas do Sal e Boavista, foram as ilhas em que os turistas permaneceram por mais tempo, cerca de 6 dias na ilha do Sal e 5 dias na ilha da Boavista. Este cenário manteve-se até 2011, ou seja, os turistas permanecem mais nestas duas ilhas.

Entre 2005 e 2010 a ilha que registou um índice de preferência mais elevado foi a ilha do Sal. A partir do ano de 2011 a ilha de Boavista passou a ser o destino turístico de maior preferência. Essa preferência pode dever-se a vários fatores, tais como:

- Criação de mais infraestruturas, como a criação do aeroporto Internacional em 2007;

- Mais oferta turística, em termos de alojamento;

- Recursos turísticos naturais como o mar, as praias e as paisagens.

\section{3. $<$ Sub-Capítulo $>$ Competitividade turística inter-ilhas}

O cálculo da quota de mercado muitas das vezes é o processo mais comum para analisar a competitividade entre diferentes destinos turísticos, utilizando diferentes fatores que explique, tais como: índice de preferência, o nível de preços relativos, o custo da viagem física e financeira, pressão competitiva exercida pela publicidade dos destinos concorrentes, entre outros (Fernandes \& González, 2007; Fernandes \& Teixeira, 2007). Para a aplicação da Análise da Quota de Mercado Faulkner foram identificados os seguintes elementos:

- Variável de desempenho: dormidas nos estabelecimentos hoteleiros, por ilha;

- Mercados emissores (origens): as 11 principais origens, as que apresentaram maior peso relativo para o destino turístico Cabo Verde em 2011: África do Sul, Alemanha, Áustria, Bélgica e Holanda, Espanha, Estados Unidos, França, Reino Unido, Itália, Portugal e Suíça;

- Destinos turísticos as ilhas de Cabo Verde: Santo Antão, São Vicente, São Nicolau, Sal, Boavista, Maio, Santiago, Fogo e Brava;

- Momentos de avaliação: ano de 2005 e 2011. 
Tabela 1: Distribuição percentual das dormidas e Índice de Gini das dormidas, ano 2011

\begin{tabular}{|c|c|c|c|c|c|c|c|c|c|c|c|}
\hline $\begin{array}{c}\text { Mercado } \\
\text { Emissor }\end{array}$ & $\begin{array}{c}\text { Cabo } \\
\text { Verde }\end{array}$ & $\begin{array}{c}\text { Santo } \\
\text { Antão }\end{array}$ & $\begin{array}{c}\text { São } \\
\text { Vicente }\end{array}$ & $\begin{array}{c}\text { São } \\
\text { Nicolau }\end{array}$ & Sal & Boavista & Maio & Santiago & Fogo & Brava & $\begin{array}{c}\text { Índice } \\
\text { de Gini }\end{array}$ \\
\hline $\begin{array}{c}\text { África do } \\
\text { Sul }\end{array}$ & 0,6 & 0,8 & 0,3 & - & 0,01 & 1 & - & 2 & - & - & $\mathbf{0 , 9 5}$ \\
\hline Alemanha & 16,8 & 15,18 & 13 & 13,1 & 17,4 & 17,2 & 18,2 & 5 & 31 & 24 & $\mathbf{0 , 8 5}$ \\
\hline Áustria & 0,5 & 1,69 & 1 & 4,3 & 0,3 & 0,6 & 1 & 0,4 & 1 & 28 & $\mathbf{0 , 8 2}$ \\
\hline $\begin{array}{c}\text { Bélgica e } \\
\text { Holanda }\end{array}$ & 6,8 & 5,04 & 6 & 30,4 & 6,1 & 7,7 & 8,8 & 3 & 2 & 8 & $\mathbf{0 , 8 7}$ \\
\hline Espanha & 2,4 & 3,62 & 15 & 4,5 & 3 & 1 & 8,2 & 8 & 2 & - & $\mathbf{0 , 7 8}$ \\
\hline $\begin{array}{c}\text { Estados } \\
\text { Unidos da } \\
\text { América }\end{array}$ & 0,5 & 0,67 & 3 & 10,8 & 0,4 & 0,2 & 3,2 & 5 & 4 & - & $\mathbf{0 , 6 7}$ \\
\hline França & 11,6 & 54,87 & 22 & 16,5 & 10,7 & 10,3 & 22,3 & 12 & 48 & 29 & $\mathbf{0 , 7 8}$ \\
\hline $\begin{array}{c}\text { Reino } \\
\text { Unido }\end{array}$ & 30,2 & 1,68 & 5 & 2,7 & 29,7 & 34,5 & 5,2 & 3 & 4 & 5 & $\mathbf{0 , 8 9}$ \\
\hline Itália & 15,7 & 4,37 & 7 & 9,9 & 19,5 & 13,7 & 12,2 & 6 & 5 & - & $\mathbf{0 , 8 7}$ \\
\hline Portugal & 13,2 & 7,21 & 26 & 6,4 & 12,3 & 11,2 & 15,2 & 54 & 3 & 5 & $\mathbf{0 , 8 0}$ \\
\hline Suíça & 1,7 & 4,87 & 2 & 1,5 & 0,5 & 2,6 & 5,8 & 1 & 1 & - & $\mathbf{0 , 9 0}$ \\
\hline $\begin{array}{c}\text { Índice de } \\
\text { Gini }\end{array}$ & $\mathbf{0 , 5 8}$ & $\mathbf{0 , 7 1}$ & $\mathbf{0 , 5 5}$ & $\mathbf{0 , 5 2}$ & $\mathbf{0 , 6 1}$ & $\mathbf{0 , 6 1}$ & $\mathbf{0 , 4 7}$ & $\mathbf{0 , 6 8}$ & $\mathbf{0 , 7 5}$ & $\mathbf{0 , 7 1}$ & - \\
\hline
\end{tabular}

Tendo por base os valores para o Índice de Gini, apresentados nas Tabelas 1 e 2, para os anos de 2005 e 2011, pode concluir-se o seguinte:

- Em termos nacionais, observa-se a uma diminuição de $0,14 \%$ da concentração de dormidas;

- O valor do índice de Gini a passar de 0,72 para 0,58, apenas São Nicolau, Sal e Boavista registam uma redução da concentração;

- Em 2005, a Itália é o mercado emissor que apresenta um maior grau de concentração da distribuição inter-ilhas das dormidas, com um índice de Gini de 0,97;

- No extremo oposto, a Áustria é o mercado emissor que apresenta o menor grau de concentração da distribuição inter-ilhas das dormidas em 2005, com um índice de 0,63;

- Em 2011, a África do Sul é o mercado emissor que apresenta um maior grau de concentração da distribuição inter-ilhas das dormidas, com um índice de 0,95;

Tabela 2: Distribuição percentual das dormidas e Índice de Gini das dormidas, ano 2005

\begin{tabular}{|c|c|c|c|c|c|c|c|c|c|c|c|}
\hline $\begin{array}{c}\text { Mercado } \\
\text { Emissor }\end{array}$ & $\begin{array}{c}\text { Cabo } \\
\text { Verde }\end{array}$ & $\begin{array}{c}\text { Santo } \\
\text { Antão }\end{array}$ & $\begin{array}{c}\text { São } \\
\text { Vicente }\end{array}$ & $\begin{array}{c}\text { São } \\
\text { Nicolau }\end{array}$ & Sal & Boavista & Maio & Santiago & Fogo & Brava & $\begin{array}{c}\text { Índice } \\
\text { de Gini }\end{array}$ \\
\hline África do Sul & 1,3 & 0,03 & 1 & 0,4 & 1,5 & 0,3 & 0,3 & 1 & 2 & 2 & $\mathbf{0 , 9 5}$ \\
\hline Alemanha & 13 & 29,23 & 11 & 15,7 & 12,5 & 24,4 & 25,3 & 11 & 24 & 46 & $\mathbf{0 , 8 7}$ \\
\hline Austria & 0,4 & 6,45 & 1 & 2 & 0,2 & 0,5 & 2 & 1 & 3 & 1 & $\mathbf{0 , 6 3}$ \\
\hline $\begin{array}{c}\text { Bélgica e } \\
\text { Holanda }\end{array}$ & 3,2 & 7,55 & 6 & 22,4 & 2,5 & 1,6 & 4,9 & 6 & 3 & 22 & $\mathbf{0 , 8 3}$ \\
\hline Espanha & 3,6 & 4,66 & 9 & 3,8 & 2,9 & 4,2 & 4,6 & 7 & 9 & 2 & $\mathbf{0 , 8 4}$ \\
\hline $\begin{array}{c}\text { Estados } \\
\text { Unidos da } \\
\text { América }\end{array}$ & 0,9 & 0,67 & 4 & 5,4 & 0,3 & 0,6 & 1,1 & 5 & 2 & 1 & $\mathbf{0 , 7 6}$ \\
\hline França & 5,9 & 27,90 & 14 & 32,5 & 3,9 & 9,4 & 14,1 & 12 & 36 & 21 & $\mathbf{0 , 7 3}$ \\
\hline Reino Unido & 1 & 6,60 & 3 & 1,5 & 0,5 & 1,1 & 10,1 & 3 & 3 & 0 & $\mathbf{0 , 7 1}$ \\
\hline Itália & 40,5 & 6,75 & 11 & 5,5 & 46,7 & 46,2 & 18,2 & 4 & 7 & 1 & $\mathbf{0 , 9 7}$ \\
\hline Portugal & 29,3 & 5,24 & 36 & 5,3 & 28,4 & 8,7 & 15,1 & 47 & 9 & 4 & $\mathbf{0 , 9 2}$ \\
\hline Suíça & 0,9 & 4,93 & 4 & 5,2 & 0,5 & 3,1 & 4,4 & 2 & 3 & 0 & $\mathbf{0 , 6 8}$ \\
\hline $\begin{array}{c}\text { Índice de } \\
\text { Gini }\end{array}$ & $\mathbf{0 , 7 2}$ & $\mathbf{0 , 5 4}$ & $\mathbf{0 , 5 5}$ & $\mathbf{0 , 5 8}$ & $\mathbf{0 , 7 8}$ & $\mathbf{0 , 7 4}$ & $\mathbf{0 , 5 1}$ & $\mathbf{0 , 6 2}$ & $\mathbf{0 , 5 7}$ & $\mathbf{0 , 7 8}$ & - \\
\hline
\end{tabular}


Os Estados Unidos da América apresenta o menor grau de concentração da distribuição inter-ilhas das dormidas em 2011, com um índice de 0,67;

A Áustria e o Reino Unido são os mercados emissores que registam maiores aumentos na concentração da distribuição das ilhas;

A Itália é a o mercado emissor em que ocorre a maior quebra da concentração.

As tabelas que seguem apresentam os resultados obtidos para o Desvio da Quota e para a Variação de Quota.

Tabela 3: Desvio da Quota de mercado das dormidas, ano 2011.

\begin{tabular}{|c|c|c|c|c|c|c|c|c|c|}
\hline $\begin{array}{c}\text { Mercado } \\
\text { Emissor }\end{array}$ & $\begin{array}{c}\text { Santo } \\
\text { Antão }\end{array}$ & $\begin{array}{c}\text { São } \\
\text { Vicente }\end{array}$ & $\begin{array}{c}\text { São } \\
\text { Nicolau }\end{array}$ & Sal & Boavista & Maio & Santiago & Fogo & Brava \\
\hline Alemanha & $-9,8$ & $-25,2$ & $-22,3$ & 3,3 & 2,2 & 8,4 & $-71,0$ & 84,5 & 45,0 \\
\hline $\begin{array}{c}\text { Bélgica e } \\
\text { Holanda }\end{array}$ & $-25,6$ & $-8,3$ & 348,0 & $-9,8$ & 13,8 & 29,3 & $-61,9$ & $-72,7$ & 17,0 \\
\hline Espanha & 50,0 & 516,4 & 86,4 & 26,0 & $-58,8$ & 241,2 & 239,5 & $-23,4$ & - \\
\hline França & 374,3 & 92,3 & 42,5 & $-7,3$ & $-10,9$ & 92,4 & 7,8 & 311,3 & 153,0 \\
\hline Itália & $-72,1$ & $-57,1$ & $-36,8$ & 24,4 & $-12,7$ & $-22,3$ & $-60,9$ & $-70,6$ & - \\
\hline Portugal & $-45,5$ & 97,3 & $-51,7$ & $-7,1$ & $-15,7$ & 14,5 & 309,9 & $-79,5$ & $-60,9$ \\
\hline Reino Unido & $-94,4$ & $-84,5$ & $-91,2$ & $-1,7$ & 14,2 & $-82,9$ & $-89,8$ & $-87,5$ & - \\
\hline
\end{tabular}

Tabela 4: Desvio da Quota de mercado das dormidas, ano 2005

\begin{tabular}{|c|c|c|c|c|c|c|c|c|c|}
\hline $\begin{array}{c}\text { Mercado } \\
\text { Emissor }\end{array}$ & $\begin{array}{c}\text { Santo } \\
\text { Antão }\end{array}$ & $\begin{array}{c}\text { São } \\
\text { Vicente }\end{array}$ & $\begin{array}{c}\text { São } \\
\text { Nicolau }\end{array}$ & Sal & Boavista & Maio & Santiago & Fogo & Brava \\
\hline Alemanha & 125,6 & $-13,5$ & 20,8 & $-3,5$ & 88,0 & 95,0 & $-14,8$ & 85,1 & 257,4 \\
\hline $\begin{array}{c}\text { Bélgica e } \\
\text { Holanda }\end{array}$ & 138,2 & 94,6 & 605,8 & $-19,9$ & $-50,8$ & 53,1 & 104,7 & 3,1 & 598,3 \\
\hline Espanha & 28,9 & 144,3 & 6,3 & $-19,5$ & 16,9 & 28,1 & 88,9 & 136,9 & - \\
\hline França & 376,4 & 143,1 & 455,1 & $-32,8$ & 60,3 & 141,1 & 101,3 & 507,0 & 262,6 \\
\hline Itália & $-83,4$ & $-72,0$ & $-86,5$ & 15,3 & 14,0 & $-55,2$ & $-89,8$ & $-83,1$ & - \\
\hline Portugal & $-82,1$ & 22,8 & $-81,8$ & $-2,8$ & $-70,2$ & $-48,5$ & 61,2 & $-70,8$ & $-87,9$ \\
\hline Reino Unido & 561,4 & 171,3 & 52,4 & $-47,8$ & 8,7 & 908,7 & 235,5 & 165,6 & - \\
\hline
\end{tabular}

Tabela 5: Variação da Quota das dormidas nas ilhas - 2011 e 2005

\begin{tabular}{|c|c|c|c|c|c|c|c|c|c|}
\hline $\begin{array}{c}\text { Mercado } \\
\text { Emissor }\end{array}$ & $\begin{array}{c}\text { Santo } \\
\text { Antão }\end{array}$ & $\begin{array}{c}\text { São } \\
\text { Vicente }\end{array}$ & $\begin{array}{c}\text { São } \\
\text { Nicolau }\end{array}$ & Sal & Boavista & Maio & Santiago & Fogo & Brava \\
\hline Alemanha & $-21,19$ & $-23,88$ & $-30,32$ & $-11,36$ & 66,26 & $-34,70$ & $-34,77$ & $-1,41$ & $-37,07$ \\
\hline $\begin{array}{c}\text { Bélgica e } \\
\text { Holanda }\end{array}$ & $-27,66$ & $-36,69$ & $-33,19$ & $-11,29$ & 129,15 & $-30,51$ & $-47,34$ & $-28,47$ & $-53,60$ \\
\hline Espanha & $-0,62$ & $-3,45$ & $-11,50$ & $-3,44$ & 47,31 & $-6,55$ & $-4,90$ & $-20,40$ & - \\
\hline França & $-4,20$ & $-27,24$ & $-47,15$ & $-6,85$ & 71,82 & $-31,09$ & $-29,57$ & $-9,86$ & $-30,69$ \\
\hline Itália & 5,87 & $-11,18$ & 6,06 & $-9,17$ & 63,41 & $-12,71$ & 8,80 & 8,81 & - \\
\hline Portugal & 17,73 & $-10,69$ & $-3,94$ & $-11,34$ & 106,79 & $-9,09$ & 1,45 & $-7,14$ & $-0,09$ \\
\hline Reino Unido & $-120,26$ & $-103,47$ & $-105,08$ & $-0,01$ & 149,84 & $-127,06$ & $-110,21$ & $-86,62$ & - \\
\hline Total & $-2,30$ & $-13,19$ & $-14,22$ & $-7,72$ & 47,38 & $-15,68$ & $-10,25$ & $-0,80$ & $-13,95$ \\
\hline
\end{tabular}


Com base nos resultados obtidos e apresentados nas tabelas anteriores, as figuras que se seguem permitem ajudar a compreender a competitividade entre ilhas - destinos turísticos -, por mercado emissor.

Para uma melhor interpretação da informação que se encontre nas figuras que se seguem utilizaram-se as seguintes siglas: A - Alemanha; B+H - Bélgica e Holanda; E - Espanha; F - França; I - Itália; R - Reino Unido.

Relembrar que o tamanho dos círculos representam a quota de mercado, onde se apresenta junto do mesmo o mercado emissor e a respetiva quota de mercado.

Da análise da figura seguinte, e para o Destino Turístico - Ilha de Santo Antão, pode observar-se:

- a elevada dependência do mercado emissor França. Na maioria dos mercados emissores verifica-se perda da quota de mercado;

- os mercados emissores que mais têm contribuído com as suas dormidas, no destino turístico em análise são, a França, Portugal, Espanha, apresentando variações médias anuais positivas de $31,4 \%, 23,8 \%, 12,6 \%$, respetivamente. Por outro lado, o emissor Reino Unido foi o único mercado emissor que registou variações médias anuais negativas de $6,5 \%$;

- em relação aos mercados emissores, a França pode ser considerada como um mercado em Declínio visto que encontra-se a perder quota de mercado e posiciona-se no quadrante de Insucesso;

- a Alemanha pode ser considerada como um mercado em Declínio na medida que se encontra a perder quota de mercado e posiciona-se no quadrante de Insucesso;

- a Espanha por sua vez é considerada como um mercado em Maturidade visto que, encontra-se a perder quota de mercado e posiciona-se no quadrante de Incerteza;

- a Bélgica e a Holanda podem ser consideradas como um mercado em Declínio, pois, encontram-se a perder esta mesma quota e posiciona-se no quadrante de Insucesso;

- o Reino Unido pode ser visto como um mercado em Declínio na medida que se encontra a perder quota de mercado e posiciona-se no quadrante de Insucesso;

- Portugal é um mercado emissor que pode ser considerado como um mercado Emergente, pois, encontra-se a ganhar quota de mercado e posiciona-se no quadrante Entrada;

- a Itália é também um mercado Emergente, visto que encontra-se a ganhar quota de mercado e posiciona-se no quadrante Entrada.

Figura 5: Destino Turístico: Ilha de Santo Antão

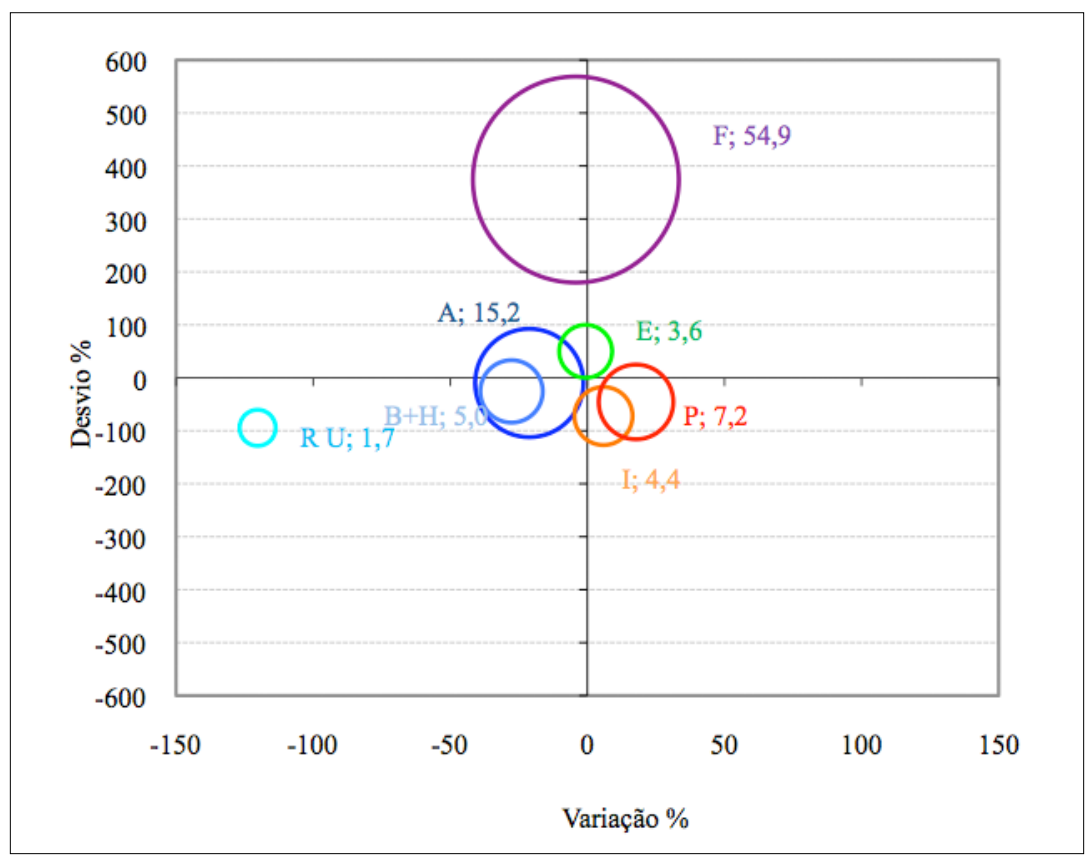


Analisando o Destino Turístico - Ilha de São Vicente (Figura 6), pode dizer-se que:

- Não denota dependências excessivas, verifica-se um desvio da quota de mercado positivo nos mercados emissores geograficamente mais próximos;

- Os mercados emissores que mais tem contribuído com as suas dormidas, no destino turístico em análise são Reino Unido, Espanha, França, Alemanha e Bélgica + Holanda, apresentando variações médias anuais positivas de $10 \%, 9,7 \%, 8,4 \%, 2,6 \%$ e $0,7 \%$ respetivamente. Por outro lado, os mercados emissores Itália e Portugal registaram variações médias anuais negativas de $7,9 \%$ e $4,6 \%$, respetivamente;

- Analisando os mercados emissores pode dizer-se que a Espanha é um mercado em Maturidade, embora esteja a perder quota de mercado, porém posiciona-se no quadrante de Incerteza;

- Portugal e a França podem ser considerado mercados em Maturidade, já que se encontram a perder quota de mercado e posicionam-se no quadrante Incerteza;

- A Bélgica e a Holanda são mercados em Declínio, pois, ambos estão a perder quota de mercado e posicionam-se no quadrante de Insucesso;

- O Reino Unido, a Itália e a Alemanha são mercados também mercados em Declínio com uma quota de mercado de $4,7 \%, 6,7 \%$ e $12,7 \%$, respetivamente.

Figura 6: Destino Turístico: Ilha de São Vicente

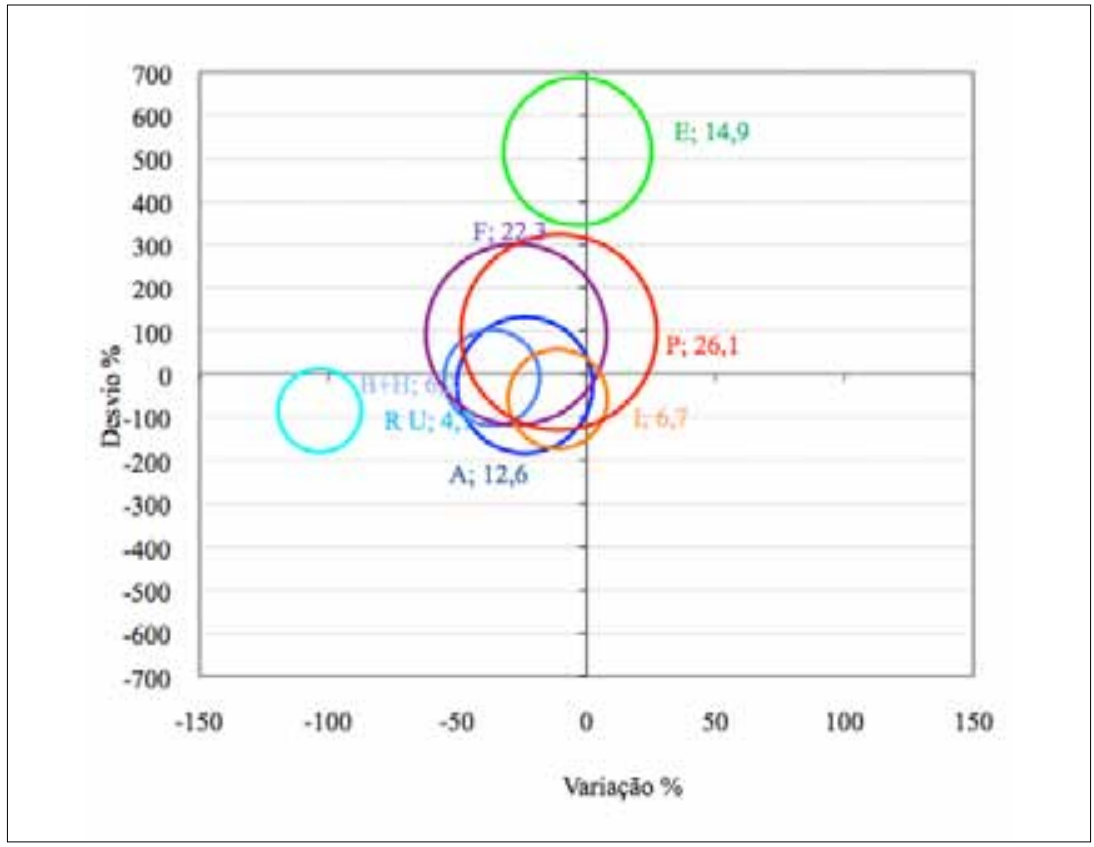

Do Destino Turístico - Ilha de São Nicolau (Figura 7), pode afirmar-se que:

- Não denota dependência excessiva, verifica-se situações de perda da quota de mercado e número elevado de mercados emissores no quadrante da incerteza;

- Os mercados emissores que mais tem contribuído com as suas dormidas, no destino turístico em análise são a Itália, o Reino Unido, a Bélgica e Holanda, apresentando variações médias anuais positivas de $9,4 \%, 8,7 \%$, e $4,2 \%$, respetivamente. Por outro lado, os mercados emissores França e Alemanha registaram variações médias anuais negativas de $11,6 \%$ e 3,9\%, respetivamente;

- Analisando os mercados emissores pode dizer-se que a Bélgica e a Holanda são mercados em Maturidade, pois, ambos perdem quota de mercado e posicionam-se no Quadrante de Incerteza;

- A França e a Espanha podem ser consideradas também como mercados em Maturidade; 
- O Reino Unido, Portugal e a Alemanha são mercados em Declínio, pois, encontram-se a perder quota de mercado e posicionam-se no quadrante de Insucesso;

- A Itália é um mercado Emergente na medida que, está a ganhar quota de mercado e posiciona-se no quadrante de Entrada.

Figura 7: Destino Turístico: Ilha de São Nicolau

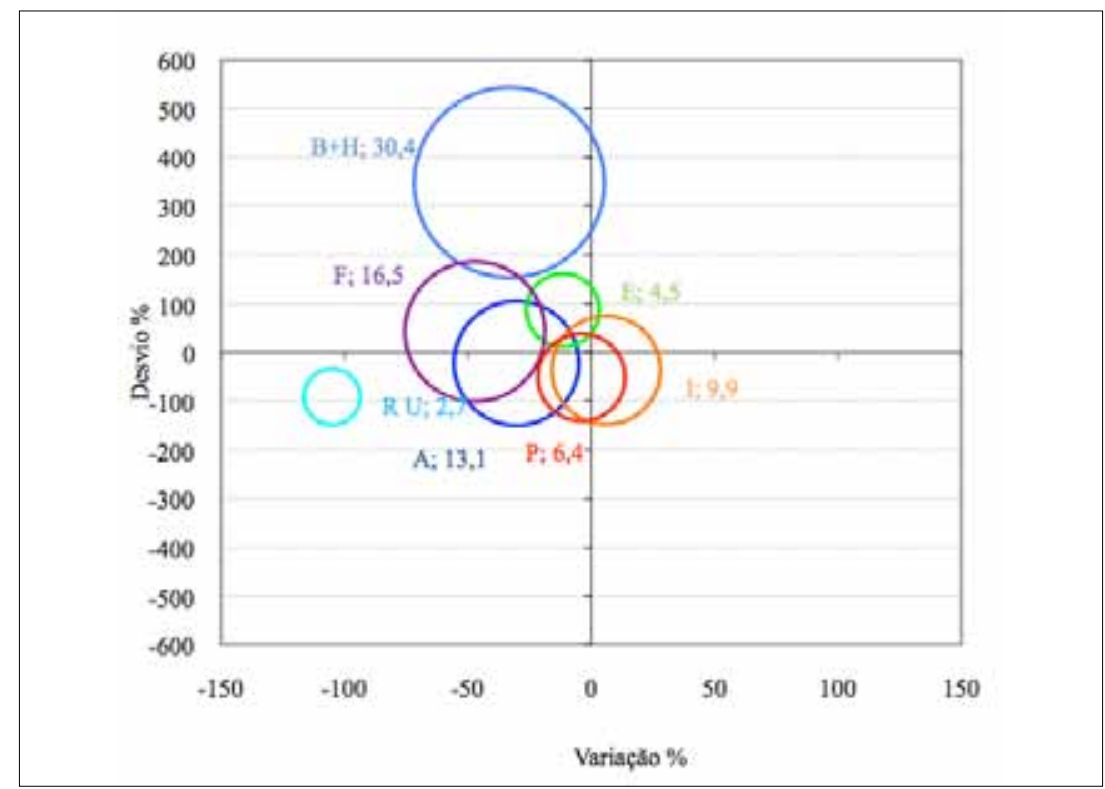

Figura 8: Destino Turístico: Ilha do Sal

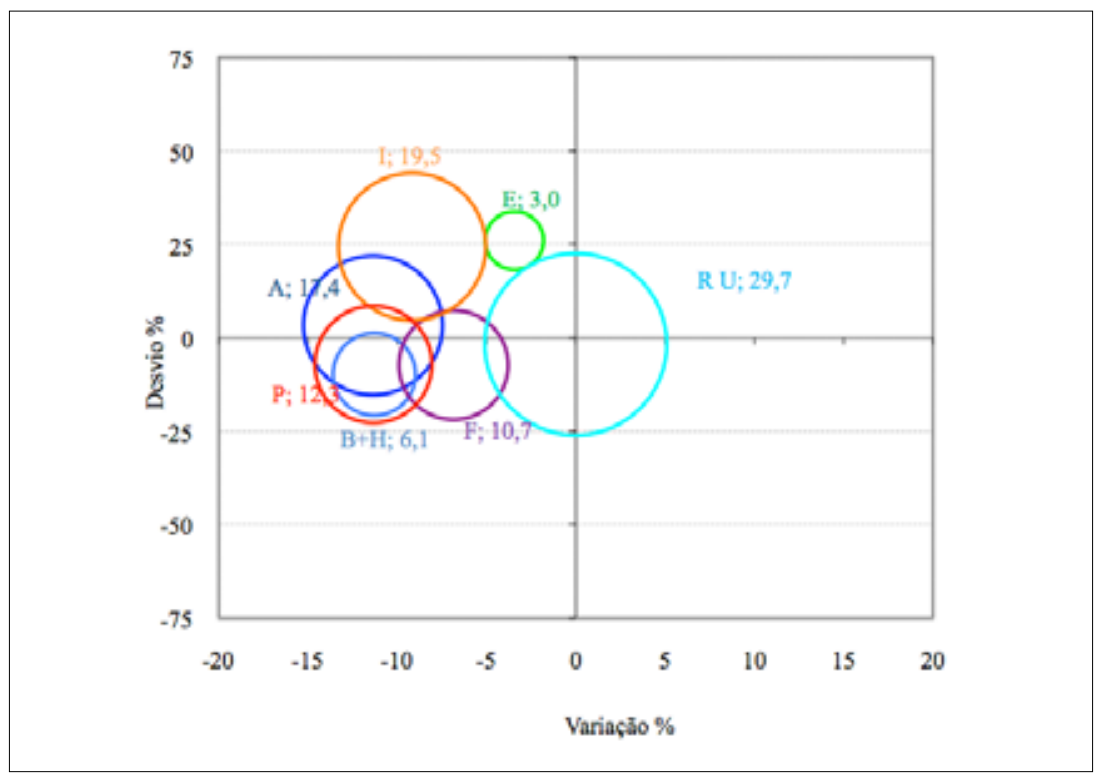


Para o Destino Turístico - Ilha do Sal (Figura 8), pode dizer-se que:

- Não denota dependência excessiva, verificam-se situações de perda da quota de mercado e número elevado de mercados emissores no quadrante de Incerteza;

- Os mercados emissores que mais tem contribuído com as suas dormidas, no destino turístico em análise são Reino Unido, França, Bélgica e Holanda e Alemanha apresentando variações médias anuais positivas de $113,7 \%, 28,7 \%, 26,1 \%$ e $15,1 \%$, respetivamente. Por outro lado, os mercados emissores Itália e Portugal registaram variações médias anuais negativas de 5,8\% e $5,3 \%$, respetivamente;

- Analisando os mercados emissores pode-se considerar a Itália, a Espanha e Alemanha como mercados em Maturidade, pois, estas encontram-se a perder quota de mercado e posicionam-se no quadrante de Incerteza;

- Portugal, a França, o Reino Unido, a Bélgica e a Holanda são mercados em declínio, encontram-se a perder quota de mercado e posicionam-se no quadrante de Insucesso.

Tendo por base a Figura 9, Destino Turístico - ilha da Boavista, pode dizer-se que:

- Não denota dependência excessiva, verifica-se situações de ganho da quota de mercado;

- Todos os mercados emissores têm contribuído com as suas dormidas, no destino turístico em análise, apresentando elevadas taxas de variações médias anuais positivas;

- Quanto aos mercados emissores, verifica-se mercados em Crescimento como, o Reino Unido, Alemanha, Bélgica e a Holanda, pois, encontram-se a ganhar quota de mercado e posicionam-se no quadrante Sucesso;

- A Itália, França, Portugal e a Espanha são mercados Emergentes, pois, os mesmos estão a ganhar quota de mercado e posicionam-se no quadrante Entrada.

Figura 9: Destino Turístico: Ilha da Boavista

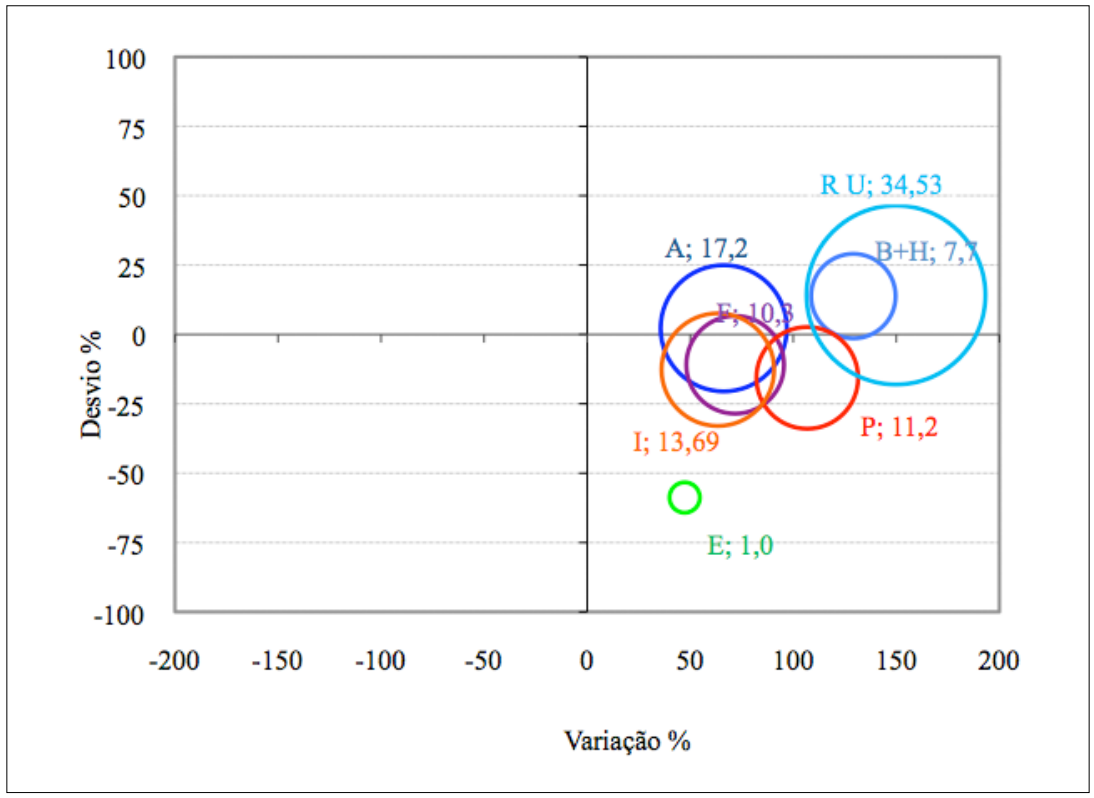

Analisando o Destino Turístico - Ilha do Maio (Figura 10), pode dizer-se que:

- Não denota dependência excessiva, desvio de quota positivo nos mercados emissores geograficamente mais próximos e número elevado de origem no quadrante de incerteza;

- Os mercados emissores que mais tem contribuído com as suas dormidas, no destino turístico em análise são Bélgica e Holanda, Espanha e França apresentando variações médias anuais positivas 
de $6,9 \%, 6,6 \%$ e 4,5\%, respetivamente. Por outro lado, os mercados emissores Reino Unido, Itália, Alemanha e Portugal registaram variações médias anuais negativas de 13,3\%, 9,4\%, 8,3\% e 3\%, respetivamente;

- Em relação aos mercados emissores, verifica-se mercados em Maturidade tais como, a Espanha, França, Portugal, Bélgica e Holanda, visto que encontram-se a perder quota de mercado e posicionam-se no quadrante Incerteza;

- A Itália, Alemanha e o Reino Unido são mercados em Declínio, estão a perder quota de mercado e posicionam-se no quadrante de Insucesso.

Figura 10: Destino Turístico: Ilha do Maio

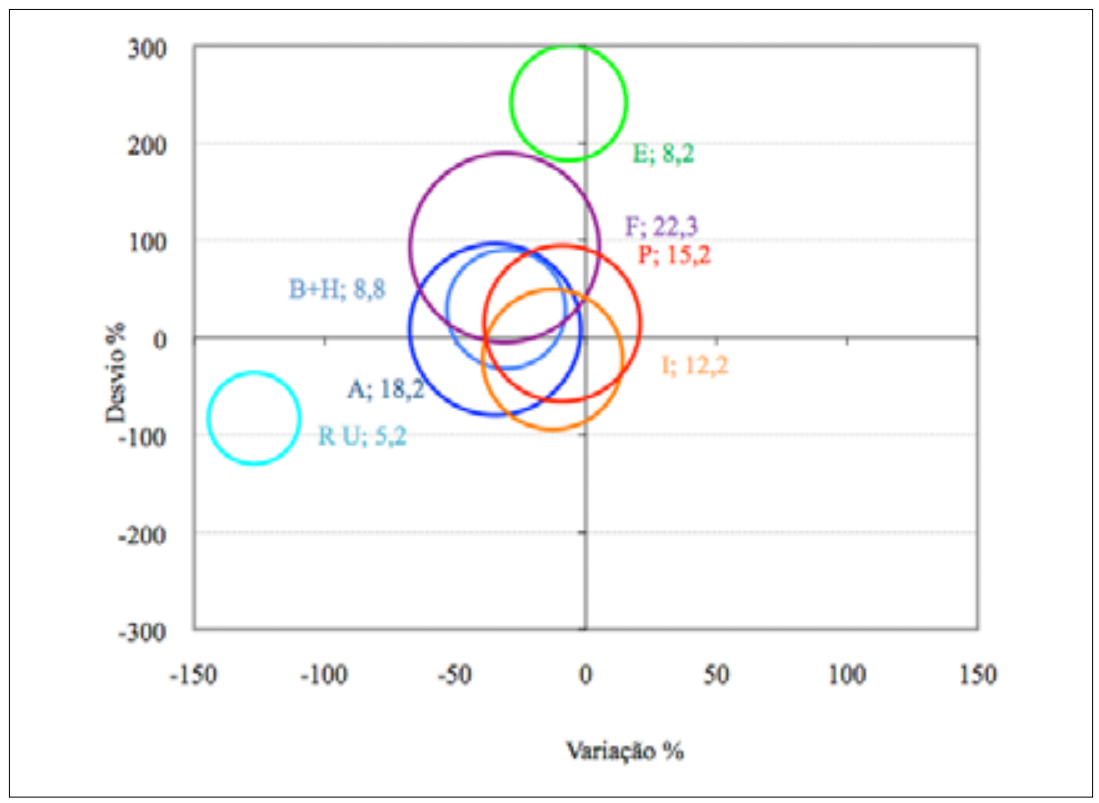

Para o Destino Turístico - Ilha de Santiago (Figura 11), pode afirmar-se que:

- Verifica-se elevada dependência do mercado emissor Portugal, desvio quota positivo nos mercados emissores geograficamente mais próximos e número elevado de mercados emissores no quadrante de Insucesso. Só não perde quota em dois mercados emissores, mas em termos globais perde quota de mercado;

- Os mercados emissores que mais tem contribuído com as suas dormidas, no destino turístico em análise são a Itália, a Espanha, Portugal e França apresentando variações médias anuais positivas de $12,1 \%, 8,3 \%, 7,5 \%$ e $6 \%$, respetivamente. Por outro lado, os mercados emissores Bélgica+Holanda e Alemanha registaram variações médias anuais negativas de 9,9\% e 8,3\%, respetivamente;

- Em relação aos mercados emissores, verifica-se Portugal como um mercado em Crescimento, está a ganhar quota de mercado e posiciona-se no quadrante Sucesso;

- A França e a Espanha são mercados em Maturidade, ambos encontram-se a perder quota de mercado e posicionam-se no quadrante de Incerteza;

- O Reino Unido, a Alemanha, Bélgica e Holanda são mercados em Declínio, pois, estão a perder quota de mercado e posicionam-se no quadrante de Insucesso;

- A Itália é um mercado Emergente, na medida que, está a ganhar quota de mercado e posiciona-se no quadrante Entrada. 
Figura 11: Destino Turístico: Ilha de Santiago

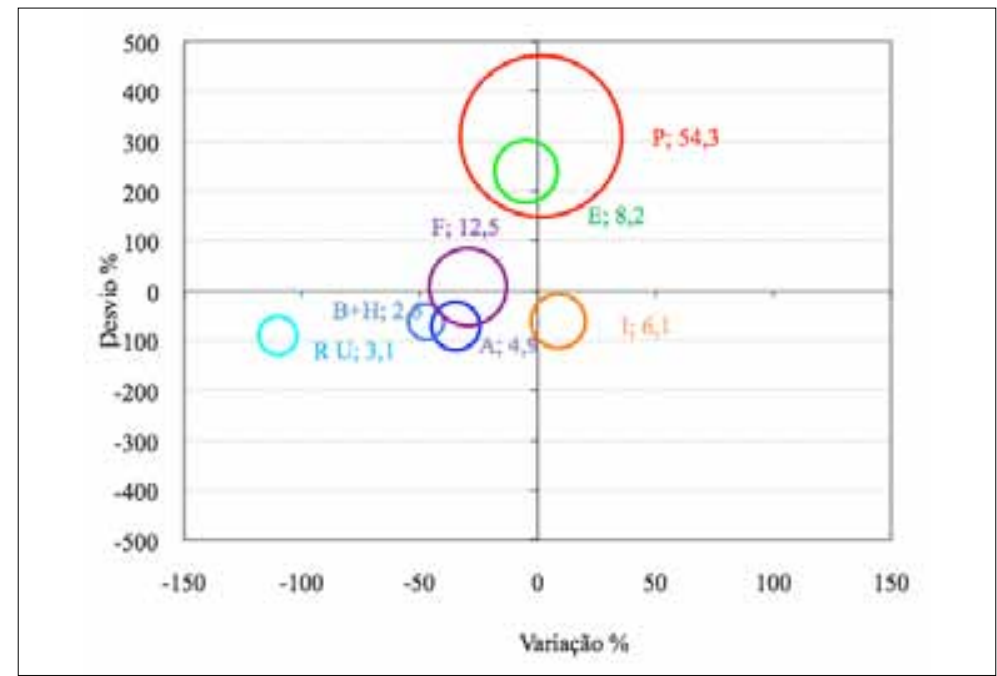

Analisando o Destino Turístico - Ilha do Fogo (Figura 12), pode dizer-se que:

Verifica-se predomínio de situações de perda de quota de mercado e número elevado de mercados emissores no quadrante de Insucesso. Só não perde quota em apenas um mercado emissor;

Os mercados emissores que mais tem contribuído com as suas dormidas, no destino turístico em análise são o Reino Unido, a França, Alemanha e Itália apresentando variações médias anuais positivas de $27,1 \%, 25,7 \%, 25 \%$ e $12,1 \%$, respetivamente. Por outro lado, os mercados emissores Espanha e Portugal registaram variações médias anuais negativas de $7,2 \%$ e $1,1 \%$, respetivamente;

Analisando os mercados emissores verificam-se mercados na fase de Maturidade, tais como, a França e Alemanha, pois, ambos encontram-se a perder quota de mercado e posicionam-se no quadrante de Incerteza;

Para além destes mercados, pode encontrar-se mercados em Declínio, tais como, a Espanha, o Reino Unido, Portugal, Bélgica e Holanda. Estes mercados encontram-se a perder quotas de mercado e posicionam-se no quadrante Insucesso;

A Itália é um mercado Emergente, está a ganhar quota de mercado e posiciona-se no quadrante Entrada.

Figura 12: Destino Turístico: Ilha do Fogo

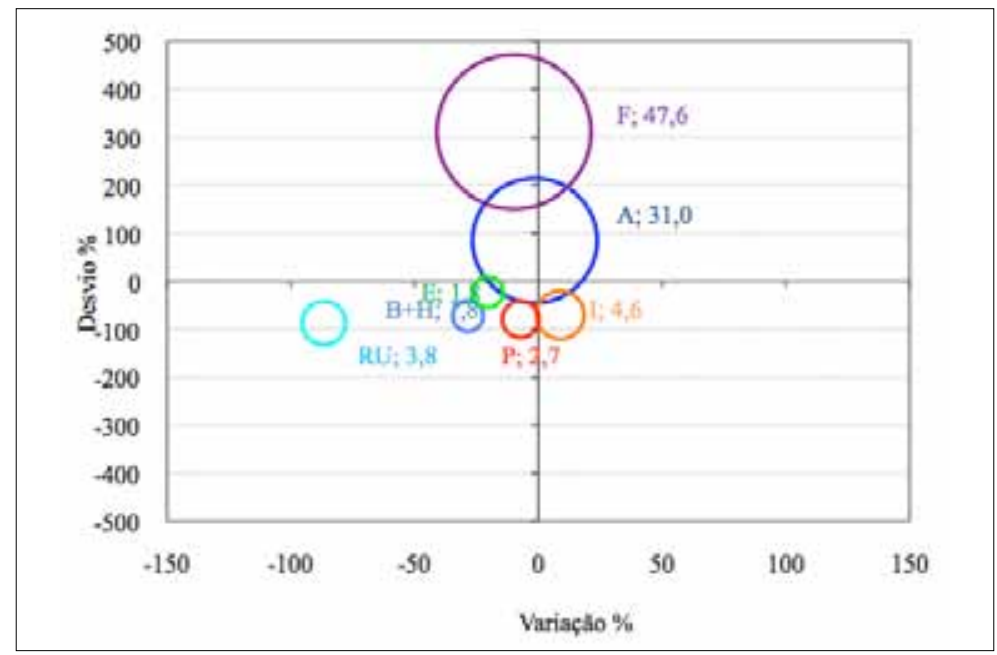


Para a Análise da Quota de Mercado para o destino turístico Brava só foram analisados 4 mercados emissores, visto que os outros 3 mercados emissores (Espanha, Itália e Reino Unido) não se registaram valores para este destino turístico. Assim, observa-se na figura seguinte:

Verifica-se predomínio de situações de perda de quota de mercado e número elevado de origem no quadrante de Insucesso. Só não perde quota em um mercado emissor;

Os mercados emissores que mais tem contribuído com as suas dormidas, no destino turístico em análise são Portugal e França, apresentando variações médias anuais positivas de 6\%, e 4,9\%, respetivamente. Por outro lado, os mercados emissores Bélgica+Holanda e Alemanha registaram variações médias anuais negativas de $16,2 \%$ e $10,6 \%$, respetivamente;

Em relação aos mercados emissores verificam-se mercados em Maturidade, tais como, a França, Alemanha, Bélgica e Holanda. Estes mercados encontram-se a perder quota de mercado e posicionam-se no quadrante de Incerteza;

Portugal é um mercado em Declínio, está a perder quota de mercado e posiciona-se no quadrante de Insucesso.

Figura 12: Destino Turístico: Ilha da Brava

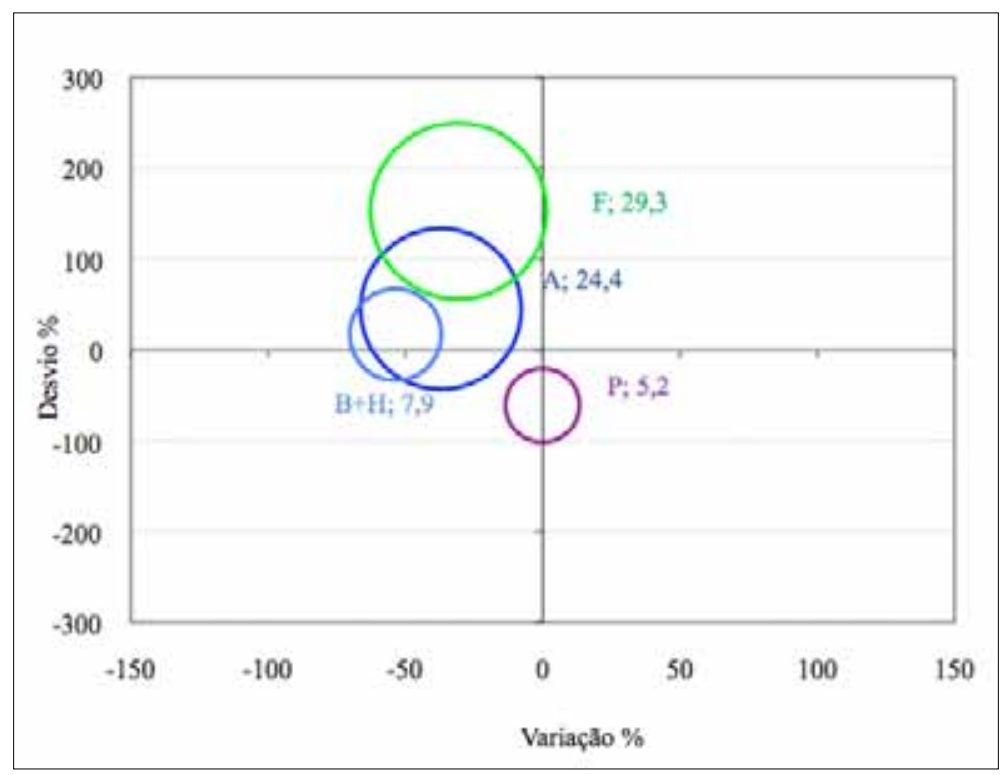

Após a análise realizada anteriormente importa completar o estudo para observar para cada par de destinos turísticos o número de vezes em que se encontram distintos nos quatro principais mercados emissores. Em termos globais, a Ilha da Boavista é a região mais singular, seguindo-se a Ilha do Sal e a Ilha de Santo Antão. A Ilha da Boavista nunca se encontra no mesmo quadrante dos destinos turísticos, São Vicente, São Nicolau, Sal, Fogo e Brava. Os pares São Nicolau e Brava são os destinos turísticos mais semelhantes entre si, encontram-se sempre no mesmo quadrante, bem como os pares Santo Antão e Boavista e o par Sal e Fogo.

Dos resultados obtidos para Análise da Quota de Mercados pode afirmar-se o seguinte:

- Destinos turísticos com posições competitivas fracas: São Nicolau, Maio e Brava;

- Destinos turísticos com posições competitivas médias: Santo Antão, São Vicente, Sal, Santiago e Fogo;

- Destino turístico com posição competitiva forte: Boavista. 


\section{Tabela 6: Dissemelhança entre os destinos turísticos nos quatro principais mercados emissores}

\begin{tabular}{|c|c|c|c|c|c|c|c|c|c|}
\hline & $\begin{array}{c}\text { Santo } \\
\text { Antão }\end{array}$ & $\begin{array}{c}\text { São } \\
\text { Vicente }\end{array}$ & $\begin{array}{c}\text { São } \\
\text { Nicolau }\end{array}$ & Sal & Boavista & Maio & Santiago & Fogo & Brava \\
\hline Santo Antão & 0 & 3 & 3 & 4 & 1 & 2 & 2 & 3 & 3 \\
\hline São Vicente & 3 & 0 & 2 & 3 & 4 & 2 & 2 & 2 & 2 \\
\hline São Nicolau & 3 & 2 & 0 & 3 & 4 & 2 & 3 & 2 & 0 \\
\hline Sal & 4 & 3 & 3 & 0 & 4 & 4 & 3 & 1 & 3 \\
\hline Boavista & 1 & 4 & 4 & 4 & 0 & 3 & 3 & 4 & 4 \\
\hline Maio & 2 & 2 & 2 & 4 & 3 & 0 & 2 & 3 & 2 \\
\hline Santiago & 2 & 2 & 3 & 3 & 3 & 2 & 0 & 2 & 3 \\
\hline Fogo & 3 & 2 & 2 & 1 & 4 & 3 & 2 & 0 & 2 \\
\hline Brava & 3 & 2 & 0 & 3 & 4 & 2 & 3 & 2 & 0 \\
\hline Total & $\mathbf{2 1}$ & $\mathbf{2 0}$ & $\mathbf{1 9}$ & $\mathbf{2 5}$ & $\mathbf{2 7}$ & $\mathbf{2 0}$ & $\mathbf{2 0}$ & $\mathbf{1 9}$ & $\mathbf{1 9}$ \\
\hline
\end{tabular}

\section{Conclusão e linhas de investigação futuras}

As ilhas de Cabo Verde são diversificadas, quer em termos físicos como socioeconómicos, uma vez que coloca a disposição dos turistas uma grande variedade em termos de oferta. O potencial turísticos das ilhas permite desenvolver diferentes tipos de turismo, desde o turismo de sol e praia (mergulho, Windsurf e pesca no alto mar); turismo de natureza (caminhadas, escaladas, passeios a cavalo, de bicicleta, entre outros); passando pelo turismo de circuitos (itinerários interessantes e pitorescos em quase todas as ilhas) ao turismo cultural que consiste no contacto direto com a cultura das ilhas, isto é, conhecer os hábitos e costumes, através das festas tradicionais, do Carnaval, da música, da gastronomia, da literatura, do artesanato, entre outros.

Pode concluir-se que em Cabo Verde o turismo é encarado como um meio de desenvolvimento do país, como tal tem-se vindo a assistir a esforços realizados no sentindo de criar e melhorar as infraestruturas turísticas de modo a estimular o setor turístico. De salientar que as melhorias não se tratam apenas ao nível de alojamento, mas toda a envolvente que poderá vir a influenciar a atividade do setor turístico, no sentido de promover as ilhas junto do público-alvo.

Assim, pode concluir-se em relação à caracterização de alguns indicadores da quota de mercado, oferta e procura do setor turístico que:

- Durante os anos em estudo verificou-se aumentos médios mais significativos no número de quartos, camas e capacidade de alojamento na ilha da Boavista;

- Número de dormidas e de hóspedes registaram-se aumentos ao longo dos anos em estudo, os quais poderão ser consequência do aumento de ofertas turísticas, campanhas promocionais entre outros;

- Os destinos turísticos Sal e Boavista foram os que registam maior número de dormidas;

- A taxa de ocupação aumentou ao longo dos anos em estudo;

- Os turistas permanecem em média entre 2 e 9 dias nos destinos turísticos, sendo que nos destinos Sal e Boavista foram os que registaram valores mais elevados para o indicador Permanência Média; - As ilhas do Sal e da Boavista são os destinos turísticos mais preferidos pelos turistas.

Relativamente à Análise da Quota de Mercado (AQM), auxiliada por medidas de concentração e taxas de crescimento, verificou-se que:

- No período de 2005 a 2011, verificaram-se alterações na competitividade turística das ilhas;

- Os destinos turísticos com posições competitivas fracas registaram as evoluções menos favoráveis e foram: as ilhas de São Nicolau, Maio e Brava;

- Os destinos turísticos com posições competitivas médias registaram as evoluções mais favoráveis e foram: as ilhas de Santo Antão, São Vicente, Sal, Santiago e Fogo;

- Boavista foi destino turístico que apresentou a posição competitiva mais elevada entre todos os destinos turísticos em análise. 
Como principal limitação do estudo refere-se à carência de informação existente sobre o Turismo referente a algumas ilhas do arquipélago, nomeadamente as ilhas de São Nicolau e Maio.

Desta forma e tendo por base a investigação realizada, sugere-se as seguintes medidas de intervenção para os destinos com posições competitivas fracas, a serem implementadas pelas respetivas entidades governamentais locais ou regionais:

- Promover e reforçar a produtividade e a competitividade das empresas do setor do turismo;

- Criar infraestruturas, equipamentos e serviços com impacto direto no desenvolvimento turístico e na qualidade da oferta, quer os que visam a requalificação e a sustentabilidade da oferta instalada, quer os que permitem potenciar oportunidades de valorização/diferenciação do produto turístico, incrementar o contributo da atividade turística para o desenvolvimento local e apoiar as atividades de animação turística;

- Dinamizar e enriquecer o calendário de animação turística e cultura, nomeadamente através do desenvolvimento de atividades de animação com conteúdos inovadores e com uma duração mais alargada;

- Promover o destino turístico, no quadro de uma estratégia de diversificação de produtos e de mercados e de projeção da sua imagem de qualidade a nível nacional e internacional.

Como principais linhas de investigação futuras, tendo por base a investigação realizada e pelas conclusões extraídas, sugere-se a construção de séries de desvio da quota e da variação da quota com base na definição de vários períodos de referência, de modo a realizar análises mais dinâmicas sobre a competitividade dos destinos turísticos.

\section{Bibliografia}

Águas, P., Grade, A., \& Sousa, P.

2003. "Competitividade Turística Regional: Avaliação nos principais mercados, 1991-2001". Estudos

Regionais, n. ${ }^{\circ}$, pp. 31-52.

Barbeitos, I.

2011. "Qualidade dos Destinos Turísticos: Desenho de um Sistema de Informação". Consultado em Fevereiro de 2014, disponível em SAPIENTA Repositório Institucional Universidade do Algarve: https://sapientia.ualg.pt/bitstream/10400.1/3112/1/Qualidade_Destinos_Turisticos-Desenho_SI.pdf Benz, A., \& Furst, D.

2002. "Policy Learning in Regional Networks". European Urban and Regional Studies, Vol. 9, n. ${ }^{\circ}$, pp. 21-35.

Buhalis, D.

2000. "Marketing the competitive destinations of the future". Tourism Management, Vol. 21, n. ${ }^{\circ}$, pp. 97-116.

Cabo Verde

2013. Câmara de turismo de Cabo Verde. Consultado em Março de 2014, disponível em: http://ctcv.cv/ ctcv/homepage/destaques/cabo-verde/\#

Costa, H., \& Hoffmann, V.

2006. "Competitividade de Destinações Turísticas: elementos e indicadores aplicados no estudo da administração turística de Balneário Camboriú”. Turismo em análise, pp. 135-154.

Dwyer, L., \& Kim, C.

2003. "Destination Competitiveness: Determinants and Indicators". Current Issues in Tourism, pp. 369-414.

Faulkner, B.

1997. "A Model for the Evaluation of National Tourism Destination Marketing Programs". Journal of Travel Research, Vol. 35, n. ${ }^{\circ}$ 3, pp. 23-32.

Fernandes, P.

2005. "Modelling, Prediction and Behaviour Analysis of Tourism Demand in the North of Portugal". $\mathrm{Ph} . \mathrm{D}$. Thesis in Applied Economy and Regional Analysis. Valladolid University-Spain. 
Fernandes, P., \& González, L.

2007. "Análisis de la Cuota del Mercado Turístico en Portugal". Actas XVII Jornadas Hispano-Lusas de Gestión Científica, Conocimiento, Innovación y Emprendedores: Camino al Futuro. Universidad de la Rioja; Logroño, Espanha; Editora Ayala Calvo, J.C. y grupo de investigación FEDRA. 2444/2455. Fernandes, P., \& Teixeira, J.

2007. "Comportamento da Procura Turística: Região Norte de Portugal". IX Seminário Luso-Espanhol de Economia Empresarial; Inovação e Educação: Ensino do Empreendedorismo.

Fernandes, P., Teixeira, J., Ferreira, J., \& Azevedo, S.

2008. "Modelação da procura turística: um estudo comparativo entre redes neuronais artificiais e a metodologia de Box-Jenkins". Actas del XII Congreso Anual Internacional de Investigación en Ciencias Administrativas (CD-ROM). Universidad del Baja California.

Hoffmann, R.

1998. "Distribuição de renda: medida de desigualdade e pobreza". Editora da Universidade de São Paulo. Manente, M.

2008. "Tourism destination management". Consultado em Março de 2014, Disponível em: http://statistics. unwto.org/sites/all/files/pdf/manente_eng_0.pdf

Mapa de Cabo Verde.

2014. Obtido em Fevereiro de 2014, da nationsonline.org: http://www.nationsonline.org/oneworld/map/ cape-verde-map.htm

Marujo, N., \& Cravidão, F.

2012. “Turismo e Lugares: Uma visão geográfica”. Revista de Turismo y Patrimonio Cultural, pp.1695-7121. $\mathrm{OMT}$

2013. "Tendências de Turismo e Estratégias de Marketing OMT'. Consultado em Janeiro de 2014, disponível em OMT:http://mkt.unwto.org/publication/unwto-tourism-highlights-2014-edition

Ritchie, J., \& Crouch, G.

1999. "Tourism Competitiveness and Societal Prosperity". Journal of Business Research, n. ${ }^{\circ}$ 44, pp. 137-152.

Ritchie, J., \& Crouch, G.

2000. "The Competitive Destination: A Sustainability Perspective". Tourism Management, Vol. 21, . $^{\circ}$ 1, pp. 1-7.

Scott, B., \& Lodge, G.

1985. "Competitiveness and the World Economy". Harvard Business School Press, Boston, Mass.

WTTC

2014. "Travel \& Tourism Economic Impact 2014 Cape Verde”. Consultado em Maio de 2014, disponível em http://www.wttc.org/ /media/files/reports/economic\%20impact\%20research/country\%20reports/ cape_verde2014.ashx. 